\title{
The Classification of Potassium Basaltic Trachyandesites that Were Discharged by the 2012-2013 Parasitic Eruption on Ploskii Tolbachik Volcano, Kamchatka Using Geochemical Criteria
}

\author{
S. A. Khubunaya ${ }^{a}$, T. S. Eremina ${ }^{a}$, and A. V. Sobolev ${ }^{b}$ \\ ${ }^{a}$ Institute of Volcanology and Seismology, Far East Branch, Russian Academy of Sciences, \\ bul'var Piipa 9, Petropavlovsk-Kamchatskii, 683006 Russia \\ e-mail: hubsa@kscnet.ru \\ ${ }^{b}$ Vernadsky Institute of Geochemistry and Analytical Chemistry, Russian Academy of Sciences, \\ ul. Kosygina 19, Moscow, 119991, GSP-1, V-334 Russia \\ Received April 16, 2015
}

\begin{abstract}
This study is concerned with the petrographic, mineralogic, and geochemical features in the K-high basaltic trachyandesites that were discharged by the 2012-2013 parasitic eruption on Ploskii Tolbachik Volcano. These K-high basaltic trachyandesites exhibit some obvious characteristics that testify to their suprasubduction origin. They are deeply differentiated rocks with strongly fractionated plagioclase. A study of the $\mathrm{Sr}, \mathrm{Nd}$, and $\mathrm{Pb}$ radiogenic isotope ratios in the $\mathrm{K}$-high basaltic trachyandesites provided evidence of their mantle origin and of the fact that the crust has exerted no influence on their compositions. We performed a comparative analysis of the ratios of the concentrations for some incoherent elements in the K-high basaltic trachyandesites, as well as in intraplate, riftogenic, and island-arc moderate potassium basalts and basaltic andesites in relation to the concentrations of these elements in the primitive mantle. The geochemical features of these K-high basaltic trachyandesites classify them as belonging to the suprasubduction subalkaline formation of the potassium series.
\end{abstract}

DOI: $10.1134 /$ S0742046316010024

\section{INTRODUCTION}

One problem that is to be resolved in the magmatic geochemistry of island arcs and continental margins consists in the causes that produced the spatial geochemical zonality. In recent years researchers have identified volcanic complexes of varying ages (not of the island-arc type) within these worldwide features, which are complexes that exhibit specific geochemical properties. Some of these complexes show $\mathrm{K}-\mathrm{Na}$ subalkaline or alkaline features that are typical of the riftogenic and intraplate geochemical rock types (Volynets et al., 1990, 1995; Perepelov, 2005, 2007, 2014), while others show considerable enrichment in light lithophile elements and belong to intraplate K-high alkaline or subalkaline geochemical types of volcanogenic formations. Long-lived volcanic centers may exhibit the replacement of island-arc (suprasubduction) calc-alkaline moderate-potassium volcanic formations with intraplate basaltoids, their subvolcanic or intrusive analogues, or vice versa. This alternation of products of volcanic activity that belong to different geochemical types has been occurring for some millions of years. In the opinion of many researchers, this was related to a tectonic restructuring of the region, which consisted either in the appearance of a rupture in the subducted oceanic plate and the appearance of a tectonic window (slab-window) or to rifting processes, deepseated fractures in the lithosphere. Both of these cases probably involved polygenic as well as deep-seated asthenospheric sources, which were possibly aided by plume action (Khanchuk and Ivanov, 1999; Flower, 1998; Perepelov, 2014, among others).

A parasitic eruption of island-arc (suprasubduction) moderate-potassium magnesian basalts occurred at an altitude of $2000 \mathrm{~m}$ on the southern slope of Ploskii Tolbachik Volcano on May 7, 1941 (Piip, 1946; Ermakov and Vazheevskaya, 1973, among others). At the same location, in the immediate vicinity of the 1941 eruption cone at an altitude of $2358 \mathrm{~m}$, on November 27, 2012 a parasitic eruption of potassium basaltic trachyandesites occurred (it was given the name of TFE-50 ${ }^{1}$ ) (Volynets et al., 2013; Gordeev et al., 2013; Dvigalo et al., 2014; Ermakov et al.,

\footnotetext{
${ }^{1}$ This is an abbreviation for the Tolbachik Fissure Eruption named after the 50 years of the establishment of the Institute of Volcanology and Seismology, Far East Branch, Russian Academy of Sciences. The name was adopted by a meeting of the Institute's Scientific Council.
} 
2014; Fedotov et al., 2014; Izbekov et al., 2014; Zelenski et al., 2014, among others). Volcanic products of different geochemical types were again found to alternate in the Tolbachik Dol ${ }^{2}$ during the Great Tolbachik Fissure Eruption (Bol'shoe ..., 1984). It should be emphasized that the eruptions on Tolbachik Volcano and those in the Tolbachik Dol took place during historical times, with no restructuring occurring in this area of Kamchatka.

Comparison of geochemical features between K-high basaltic trachyandesites and the products of volcanic activity produced under different geodynamic settings may furnish some information toward resolving the problem of their origin and their formational affiliation.

The study of K-high basaltic trachyandesites also has important practical applications. A 1-kg sample was taken from a lava flow during the 2013 eruption of these rocks and was found to contain 700 diamond marks (Gordeev et al., 2014). Clarification of the geochemical formational affiliation of these rocks is important, because it can aid our understanding of the conditions that prevailed during their generation; hence it can facilitate the detection of diamonds in volcanic ejecta that exhibit the same geochemical characteristics. It is especially important to be able to make artificial diamonds by applying the results of geochemical studies in the conditions of generation of these rare minerals.

The goal of the present study is to clarify the geochemical formational affiliation of K-high basaltic trachyandesites. One knows that the trends in the distribution of incompatible elements in igneous rocks are controlled by their concentrations at the source and by mineral-melt equilibria during the evolution of parent magmas (Interpretatsiya ..., 2001). The best method for evaluating the formational affiliation of volcanic rocks under comparison using geochemical criteria consists in constructing plots (spider diagrams) that characterize the ratios of concentrations for incompatible elements in the primitive (undepleted) mantle as originally proposed by American researchers in their studies of Pacific basalts (Wood, 1979; Holm, 1985). This is especially important, because the method makes use of the entire range of incompatible elements that were the first to go into the melt during the melting of the source. For this reason they provide the most reliable information from which to deduce the formational affiliation of the parent magma melts. We used this method to make a comparison between the geochemical features of the 2012-2013 K-high basaltic trachyandesites and those of the main geochemical rock types that occur all over Kamchatka. Comparison of geochemical and isotope compositions for all of the volcanic rocks under study must help toward clarifying the genesis of K-high basaltic trachyandesites and the interpretation of their source.

\footnotetext{
2 olbachik Dol is a volcanic plateau at an altitude of $900 \mathrm{~m}$ in the area of Ostryi Tolbachik and Ploskii Tolbachik volcanoes.
}

\section{THE SAMPLES AND METHODS FOR THEIR STUDY}

The active Ploskii Tolbachik Volcano is situated in the south of the Klyuchevskoi Volcanic Cluster. The objects of study were lavas, bombs, ashes, and crystalline plagioclase lapilli. The sampling was carried out during the eruption by the volcanological teams that were on duty and by the authors of this publication during the field work of 2013 (Fig. 1). We studied the petrographic, mineralogic, and geochemical features of all of the volcanic rocks. The ejecta were studied for major and rare elements by first crushing them in the same ferromanganese mortar and then grinding them in a jasper grinder.

We studied the rock-forming minerals, olivines, pyroxenes, and plagioclases in the K-high basaltic trachyandesites in bromoform-enriched fractions in detail. Some minerals were studied in polished sections. A detailed account of the technique that was employed for the preparation of minerals that were studied using an $\mathrm{X}$-ray spectral microanalyzer can be found in (Khubunaya et al., 1993).

The leading elements of the TFE-50 high potassium basaltic trachyandesites were studied by X-ray fluorescence analysis on glass disks using a PANalytical Axios wave dispersive spectrometer at the Advanced Instrumentation Laboratory, University of Fairbanks, Alaska. Preliminary calibration was performed using the AGV-1, BHVO-1, BIR-1, JB-2, JGb-1, JP-1, and JR-1 standards. Some samples were analyzed for major elements by $\mathrm{X}$-ray fluorescence at the Vernadskii Institute of Geochemistry and Analytical Chemistry, Moscow as described in (Roshchina et al., 1971).

The concentrations of admixture elements in the Ploskii Tolbachik K-high basaltic trachyandesites were determined at the Analytical Certification Testing Center of the Institute of Microelectronic Technology Problems and Very Pure Materials, Russian Academy of Sciences (ACTC IMTP RAS, Chernogolovka, Russia). The relative standard error for all the elements that were found does not exceed 0.2 when the concentrations that were measured were below 5 rel. $\%$ and does not exceed 0.1 with concentrations that were greater than 5 rel. \% (Karandashev et al., 2008).

The admixture elements in moderate potassium basalts and basaltic andesites were determined using the LA-ICP MS technique with a laser sampler. This study used an ELEMENT-2 Thermo Scientific mass spectrometer with an UP-213 New Wave Research solid-body laser at the Max Planck Institute for Chemistry in Mainz, Germany. The error of the concentration, which was determination as estimated from the standard reproducibility did not exceed 5 rel. \% (two standard errors) for concentrations greater than $1 \mathrm{~g} / \mathrm{t}$ and $10 \mathrm{rel} . \%$ for those of approximately $1.1 \mathrm{~g} / \mathrm{t}$ (Sobolev et al., 2009). 


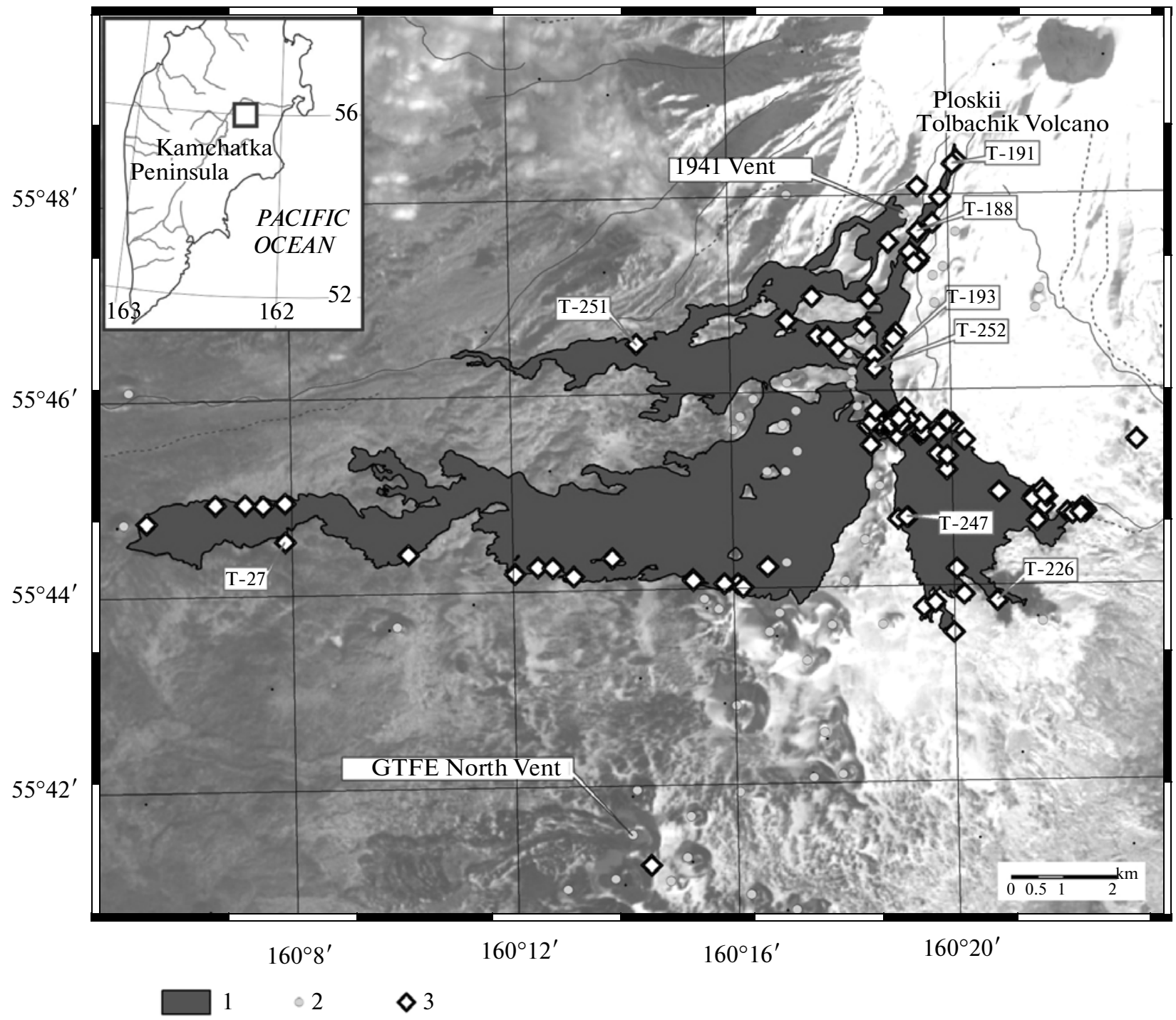

Fig. 1. A map showing sampling sites on the lava flow from the parasitic eruption of 2012-2013 on Ploskii Tolbachik Volcano. Lava flows of K-high basaltic trachyandesites, (2) peaks of historical and prehistoric cones, (3) sites where lava flows and volcanic bombs were sampled. The image of lava flows is based on a photograph made from on board the EO-1 satellite, with modifications by V.N. Dvigalo and I.M. Romanova.

Olivines, clinopyroxenes, and plagioclases were analyzed at the Institute of Volcanology and Seismology, Far East Branch (FEB), Russian Academy of Sciences (RAS) using a CAMEBAX X-ray spectral microanalyzer and at the Max Planck Institute for Chemistry in Mainz, Germany using the technique that was outlined in (Sobolev et al., 2009).

The $\mathrm{Sr}$ and $\mathrm{Nd}$ isotope compositions were studied at the Vernadskii Institute of Geochemistry and Analytical Chemistry using a modified TSN 206 SA mass spectrometer with a three-banded ion source. The measured isotope $\mathrm{Nd}$ ratios were normalized according to ${ }^{150} \mathrm{Nd} /{ }^{142} \mathrm{Nd}$ $=0.209627$ using $\left({ }^{143} \mathrm{Nd} /{ }^{144} \mathrm{Nd}\right)_{\text {chur }}=0.512638$.

The isotope composition of lead was determined at the Karpinskii All-Russia Institute of Geological Research
(FGUP VSEGEI, St. Petersburg) by thermal-emission mass spectrometry using a solid state mass spectrometer with a solid-state ionization source (Berzina et al., 2013).

\section{THE PETROGRAPHIC AND MINERALOGIC CHARACTERISTICS OF THE ROCKS}

The K-high basaltic trachyandesites that were discharged by Ploskii Tolbachik in 2012-2013 are aphyric and subaphyric rocks (Figs. 2a and 2b). The total amount of plagioclase, olivine, and clinopyroxene phenocrysts can be as high as $2-3 \%$. Plagioclase occurs in the form of tabular crystals that reach a few centimeters across. The plagioclase phenocrysts generally exhibit direct zonality, while their compositions vary between $\mathrm{An}_{51} \mathrm{Ab}_{43} \mathrm{Ort}_{4}$ and 

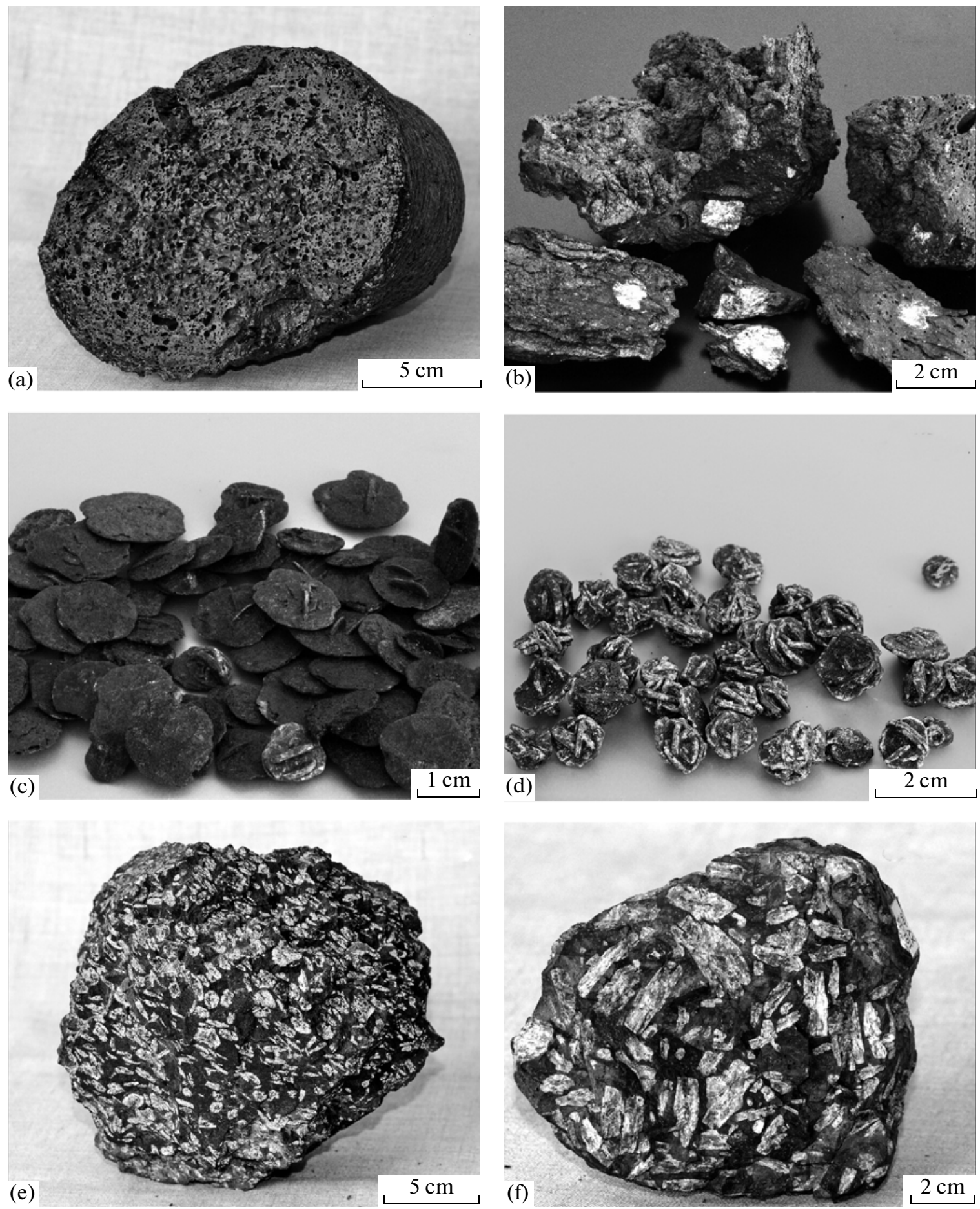

Fig. 2. The products of volcanic activity during the parasitic eruption of 2012-2013 on Ploskii Tolbachik.

(a), a volcanic bomb of subaphyric K-high basaltic trachyandesites (no. T-95); (b), subaphyric K-high basaltic trachyandesites (no. T-256); (c), lamellae of plagioclase lapilli (no. GF-253); (d), growths of plagioclase lapilli (no. GF-254); (e), plagioclase cumulate from a volcanic bomb ejected by the First Cone of the GTFE North Vent (no. 101-83); (f), plagioclase cumulate from a volcanic bomb ejected by the Lavovyi Shish Vent on Mt. Sopka Dal'nyaya (no. 101-14), B.I. Piip's collection.

$\mathrm{An}_{83} \mathrm{Ab}_{16} \mathrm{Ort}_{1}$. They are frequently resorbed by glass. One especially notes crystalline plagioclase lapilli, which were mostly discharged early during the eruption. They occur in the form of plagioclase growths and isolated tablets that can be as large as $1.5 \mathrm{~cm}$ across (see Figs. 2b, 2c, and 2d). The compositions of the tablets and plagioclase growths, as well as of crystalline lapilli, vary widely. They typically exhibit a cellular structure of chemical composition. Indi- 
Table 1. Representative compositions of lava flows that consist of K-high basaltic trachyandesites that were discharged by the 2012-2013 parasitic eruption on Ploskii Tolbachik Volcano

\begin{tabular}{|c|c|c|c|c|c|c|c|}
\hline Element/no. & T-193 & $\mathrm{T}-246$ & $\mathrm{~T}-252$ & $\mathrm{~T}-191$ & $\mathrm{~T}-188$ & $\mathrm{~T}-251$ & $\mathrm{~T}-27$ \\
\hline $\mathrm{SiO}_{2}$ & 51.89 & 51.86 & 52.12 & 54.399 & 54.688 & 54.91 & 52.62 \\
\hline $\mathrm{TiO}_{2}$ & 2.02 & 2.02 & 1.82 & 1.78 & 1.78 & 1.58 & 1.97 \\
\hline $\mathrm{Al}_{2} \mathrm{O}_{3}$ & 16.21 & 16.03 & 16.92 & 16.42 & 16.65 & 17.32 & 15.91 \\
\hline $\mathrm{FeO}$ & 11.39 & 11.93 & 10.68 & 9.05 & 9.13 & 9.81 & 10.25 \\
\hline $\mathrm{MnO}$ & 0.18 & 0.15 & 0.15 & 0.17 & 0.17 & 0.14 & 0.18 \\
\hline $\mathrm{MgO}$ & 4.24 & 4.25 & 2.71 & 3.05 & 3.05 & 3.01 & 3.92 \\
\hline $\mathrm{CaO}$ & 7.58 & 7.41 & 7.61 & 6.92 & 6.94 & 7.05 & 7.58 \\
\hline $\mathrm{Na}_{2} \mathrm{O}$ & 3.41 & 3.93 & 3.86 & 3.78 & 3.82 & 4.01 & 3.45 \\
\hline $\mathrm{K}_{2} \mathrm{O}$ & 2.45 & 2.47 & 2.23 & 2.69 & 2.72 & 2.48 & 2.46 \\
\hline $\mathrm{P}_{2} \mathrm{O}_{5}$ & 0.61 & 0.48 & 0.53 & 0.65 & 0.65 & 0.57 & 0.66 \\
\hline Total & 99.98 & 100.53 & 98.63 & 98.92 & 99.59 & 100.88 & 99.00 \\
\hline $\mathrm{Rb}$ & 71 & 76 & 58 & 68 & 72 & 57 & 59 \\
\hline $\mathrm{Ba}$ & 617 & 536 & 543 & 613 & 609 & 567 & 550 \\
\hline $\mathrm{Th}$ & 3.1 & 3.0 & 3.2 & 3.5 & 3.6 & 3.4 & 3.3 \\
\hline $\mathrm{U}$ & 1.8 & 1.7 & 1.9 & 2.0 & 2.0 & 1.9 & 1.9 \\
\hline $\mathrm{Nb}$ & 7.6 & 7.2 & 8.8 & 8.7 & 8.8 & 8.7 & 8.6 \\
\hline $\mathrm{Ta}$ & 0.50 & 0.45 & 0.55 & 0.63 & 0.66 & 0.62 & 0.57 \\
\hline $\mathrm{K}$ & 20338 & 20504 & 18512 & 22331 & 22605 & 20587 & 20421 \\
\hline $\mathrm{La}$ & 24.3 & 22.0 & 22.9 & 24.2 & 23.7 & 22.5 & 22.7 \\
\hline $\mathrm{Ce}$ & 60.3 & 58.9 & 57.8 & 61.1 & 61.4 & 55.7 & 58 \\
\hline $\mathrm{Pb}$ & 7.3 & 7.2 & 7.5 & 8.7 & 8.7 & 8.2 & 7.5 \\
\hline $\operatorname{Pr}$ & 8.0 & 7.8 & 8.3 & 8.5 & 8.5 & 7.9 & 8.2 \\
\hline $\mathrm{Nd}$ & 37.8 & 35.8 & 37.8 & 39.2 & 39.9 & 36.5 & 37.8 \\
\hline $\mathrm{Sr}$ & 329 & 318 & 300 & 321 & 324 & 296 & 311 \\
\hline $\mathrm{Sm}$ & 8.9 & 8.4 & 9.2 & 9.4 & 9.6 & 9.0 & 9.1 \\
\hline $\mathrm{Zr}$ & 289 & 265 & 290 & 309 & 308 & 290 & 280 \\
\hline $\mathrm{Hf}$ & 6.4 & 5.6 & 7.0 & 7.3 & 7.4 & 7.3 & 6.9 \\
\hline $\mathrm{Eu}$ & 2 & 2 & 3 & 3 & 3 & 2 & 2.5 \\
\hline $\mathrm{Ti}$ & 12108 & 12108 & 10909 & 10669 & 10669 & 94706 & 11808 \\
\hline $\mathrm{Gd}$ & 9.1 & 8.7 & 9.4 & 9.8 & 10.0 & 9.1 & 9.2 \\
\hline $\mathrm{Tb}$ & 1.4 & 1.3 & 1.4 & 1.5 & 1.5 & 1.4 & 1.4 \\
\hline Dy & 8.1 & 7.6 & 8.6 & 8.8 & 9.0 & 8.3 & 8.3 \\
\hline Ho & 1.7 & 1.5 & 1.7 & 1.8 & 1.8 & 1.7 & 1.7 \\
\hline$Y$ & 49 & 46 & 47 & 49 & 50 & 44 & 45.5 \\
\hline $\mathrm{Er}$ & 5.0 & 4.6 & 5.1 & 5.3 & 5.5 & 5.0 & 5 \\
\hline $\mathrm{Tm}$ & 0.70 & 0.64 & 0.72 & 0.75 & 0.77 & 0.70 & 0.7 \\
\hline $\mathrm{Yb}$ & 4.7 & 4.3 & 4.7 & 5.0 & 5.1 & 4.6 & 4.6 \\
\hline $\mathrm{Lu}$ & 0.71 & 0.65 & 0.71 & 0.77 & 0.78 & 0.72 & 0.71 \\
\hline $\mathrm{Ni}$ & 42 & 38 & 37 & 5 & 5 & 6 & 25 \\
\hline $\mathrm{Cu}$ & 303 & 340 & 317 & 231 & 222 & 218 & 330 \\
\hline $\mathrm{Zn}$ & 121 & 131 & 123 & 124 & 121.594 & 109 & 124 \\
\hline
\end{tabular}


Table 1. (Contd.)

\begin{tabular}{|c|c|c|c|c|c|c|c|}
\hline Element/no. & $\mathrm{T}-193$ & $\mathrm{~T}-246$ & $\mathrm{~T}-252$ & $\mathrm{~T}-191$ & $\mathrm{~T}-188$ & $\mathrm{~T}-251$ & $\mathrm{~T}-27$ \\
\hline $\mathrm{Sc}$ & 24 & 24 & 22 & 20 & 22 & 20 & 24 \\
\hline $\mathrm{Co}$ & 31 & 30 & 28 & 18 & 19 & 19 & 26 \\
\hline $\mathrm{Li}$ & 18 & 19 & 17 & 19 & 19 & 18 & 17 \\
\hline V & 309 & 349 & 322 & 250 & 244 & 244 & 335 \\
\hline W & 0.56 & 0.55 & 0.55 & 0.67 & 0.71 & 0.64 & 0.58 \\
\hline $\mathrm{Be}$ & 1.7 & 1.8 & 1.7 & 1.9 & 1.8 & 1.6 & 1.6 \\
\hline $\mathrm{Cr}$ & 39 & 38 & 36 & - & - & - & 16 \\
\hline $\mathrm{Ga}$ & 22.7 & 21.1 & 23.9 & 23.4 & 23.6 & 23.3 & 24.6 \\
\hline Cs & 2.3 & 2.3 & 2.2 & 2.4 & 2.7 & 2.2 & 2.2 \\
\hline $\mathrm{Sb}$ & 0.52 & 0.47 & 0.43 & 0.62 & 0.65 & 0.53 & 0.45 \\
\hline $\mathrm{Bi}$ & 0.035 & 0.040 & 0.044 & 0.082 & 0.052 & 0.112 & 0.06 \\
\hline As & 1.5 & 0.8 & n.d. & n.d. & n.d. & n.d. & n.d. \\
\hline Mo & 2.3 & 2.2 & 2.3 & 2.6 & 2.7 & 2.5 & 2.3 \\
\hline $\mathrm{Ag}$ & 0.14 & 0.17 & 0.13 & 0.22 & 0.18 & 0.14 & 0.12 \\
\hline $\mathrm{Cd}$ & 0.058 & 0.071 & - & 0.075 & - & - & 0.043 \\
\hline $\mathrm{Tl}$ & 0.08 & 0.09 & 0.10 & 0.18 & 0.37 & 0.26 & 0.07 \\
\hline $\mathrm{Ba} / \mathrm{Nb}$ & 81 & 75 & 62 & 70 & 70 & 65 & 64 \\
\hline $\mathrm{Sr} / \mathrm{Nb}$ & 43 & 44 & 34 & 37 & 37 & 34 & 38 \\
\hline $\mathrm{Rb} / \mathrm{Ba}$ & 0.12 & 0.14 & 0.11 & 0.12 & 0.12 & 0.10 & 0.11 \\
\hline $\mathrm{Ta} / \mathrm{Yb}$ & 0.11 & 0.11 & 0.12 & 0.13 & 0.13 & 0.13 & 0.12 \\
\hline $\mathrm{Nb} / \mathrm{Yb}$ & 1.637 & 1.677 & 1.863 & 1.738 & 1.711 & 1.878 & 1.87 \\
\hline $\mathrm{La} / \mathrm{Yb}$ & 5.2 & 5.1 & 4.9 & 4.8 & 4.6 & 4.8 & 4.9 \\
\hline $87 \mathrm{Sr} / 86 \mathrm{Sr}$ & 0.70336 & 0.70336 & 0.70341 & 0.70339 & 0.70338 & 0.70338 & 0.70337 \\
\hline $143 \mathrm{Nd} / 144 \mathrm{Nd}$ & 0.51310 & 0.51310 & 0.51309 & 0.51309 & 0.51309 & 0.51310 & 0.51310 \\
\hline $206 \mathrm{~Pb} / 204 \mathrm{~Pb}$ & 18.21081 & 18.19537 & 18.18919 & 18.19552 & 18.17651 & 18.18285 & 18.14220 \\
\hline $207 \mathrm{~Pb} / 204 \mathrm{~Pb}$ & 15.50386 & 15.48424 & 15.47554 & 15.48088 & 15.46267 & 15.46621 & 15.41160 \\
\hline $208 \mathrm{~Pb} / 204 \mathrm{~Pb}$ & 37.98343 & 37.91659 & 37.88526 & 37.90351 & 37.84295 & 37.85738 & 37.67360 \\
\hline
\end{tabular}

Sample nos. correspond with those in Fig. 1. In addition to our samples, we also used samples from G.B. Flerov's collections (T-252) (a volcanic bomb). Oxides in samples T-193, T-191, T-188 from P.A. Izbekov's collection were determined at Advanced Instrumentation Laboratory, University of Fairbanks, Alaska. Oxides are given in wt \%, admixture elements in g/t. n.d. stands for Not Determined.

vidual adjacent patches that are in immediate contact in a plagioclase tablet may have very different compositions, from $\mathrm{An}_{60} \mathrm{Ab}_{36} \mathrm{Ort}_{3}$ to $\mathrm{An}_{80} \mathrm{Ab}_{19} \mathrm{Ort}_{1}$. Zonality is absent from such plagioclase tablets. Individual tablets and plagioclase lapilli growths have shapes that resemble those discharged at the GTFE South Vent (Bol'shoe ..., 1984) and during the summit caldera eruption of Ploskii Tolbachik Volcano (Markhinin et al., 1973); however, the present structures are smaller. It is not our intention to study the crystallographic phenomenon of plagioclase lapilli. Olivine and augite phenocrysts are encountered in much lower amounts. These minerals are $1 \mathrm{~mm}$ across at the largest. The magnesium number of the olivine phenocrysts lies in the range $\mathrm{Fo}_{77-69}$ (Fig. 3). The clinopyroxene phenocrysts are consistent with augite, Mg\#78-69 (Fig. 3). The above petrographic analysis suggests that olivine and clinopyroxene were crystallized last, after plagioclase. The groundmass of basaltic trachyandesites is a porous substance that appears to be brown in transmitted light. The substance contains spicular microlites of plagioclase, olivine, augite, and magnetite.

\section{THE GEOCHEMICAL FEATURES OF K-HIGH BASALTIC TRACHYANDESITES AND MODERATE POTASSIUM BASALTS AND BASALTIC ANDESITES}

The data points for the volcanic rocks that were discharged during the 2012-2013 parasitic eruption on Ploskii Tolbachik plot in the classification diagram (Petrograficheskii ..., 2009) in the field of basaltic trachyandesites (Fig. 4). One notices increasing alkalies to be concurrent with increasing $\mathrm{SiO}_{2}$ in basaltic trachyandesites. The alkalies essentially lie along the extension of the trend of high-potassium silica-rich basalts ${ }^{3}$ (trachybasalts) that were discharged at the GTFE South Vent in 1975-1976 (Bol'shoe ..., 1984). The concentration of $\mathrm{Na}_{2} \mathrm{O}$ in the $\mathrm{K}$ high basaltic trachyandesites is similar to the one that is found in the calc-alkaline moderate potassium series (Table 1). At the same time, the concentrations of $\mathrm{K}_{2} \mathrm{O}$ in the basaltic trachyandesites are higher than those to be found in moderate potassium rocks in ratios of 2 to 2.7

\footnotetext{
${ }^{3}$ The rock names are given after (Bol'shoe ..., 1984).
} 

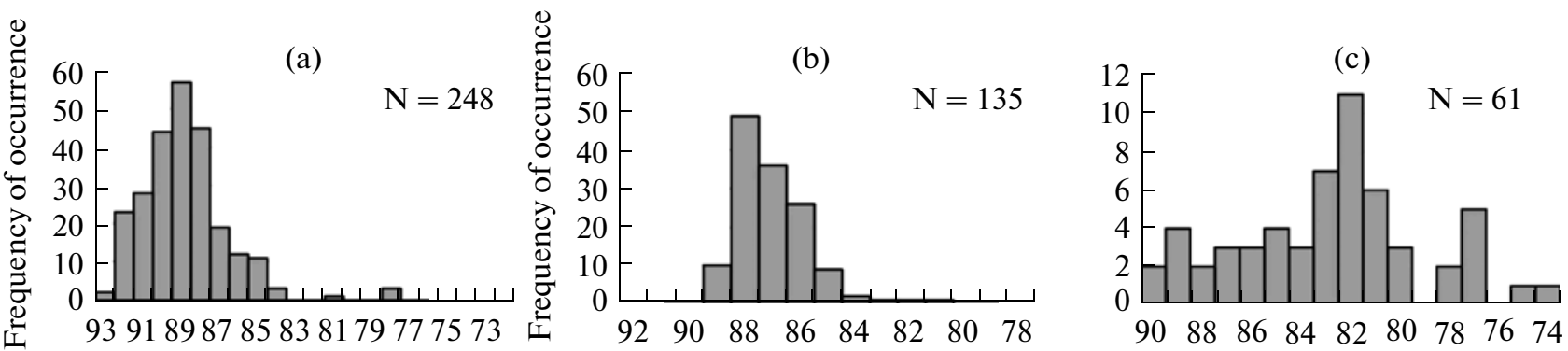

$\mathrm{Mg} \times 100 / \mathrm{Mg}+\mathrm{Fe}^{2+}, \mathrm{mol} \%$ $\mathrm{Mg} \times 100 / \mathrm{Mg}+\mathrm{Fe}^{2+}, \mathrm{mol} \%$

$\mathrm{Mg} \times 100 / \mathrm{Mg}+\mathrm{Fe}^{2+}, \mathrm{mol} \%$
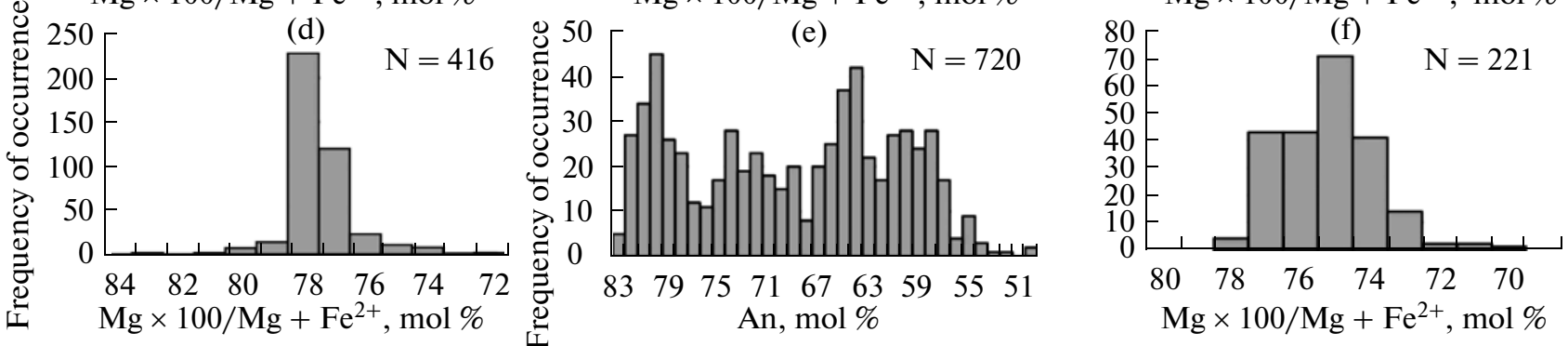

Fig. 3. The mineral compositions of basalts and K-high basaltic trachyandesites, the Klyuchevskoi Volcanic Cluster.

(a), olivines of moderate potassium magnesian basalt in a lava flow, unnamed cone (no. 11-3), Klyuchevskoi Volcano; (b), olivines of moderate potassium magnesian basalt in a lava flow, Second Cone of the GTFE North Vent (no. 101-88), Tolbachik Dol. Ploskii Tolbachik Volcano: (c), olivines of moderate potassium magnesian basalt in a lava flow, parasitic vent of 1941 (no. 10129); j, K-high basaltic trachyandesites (T-191): (d), olivine, (e), plagioclase, (f), clinopyroxene. N denotes the number of measurements. The cones on Klyuchevskoi Volcano are those in (Ermakov, 1977).

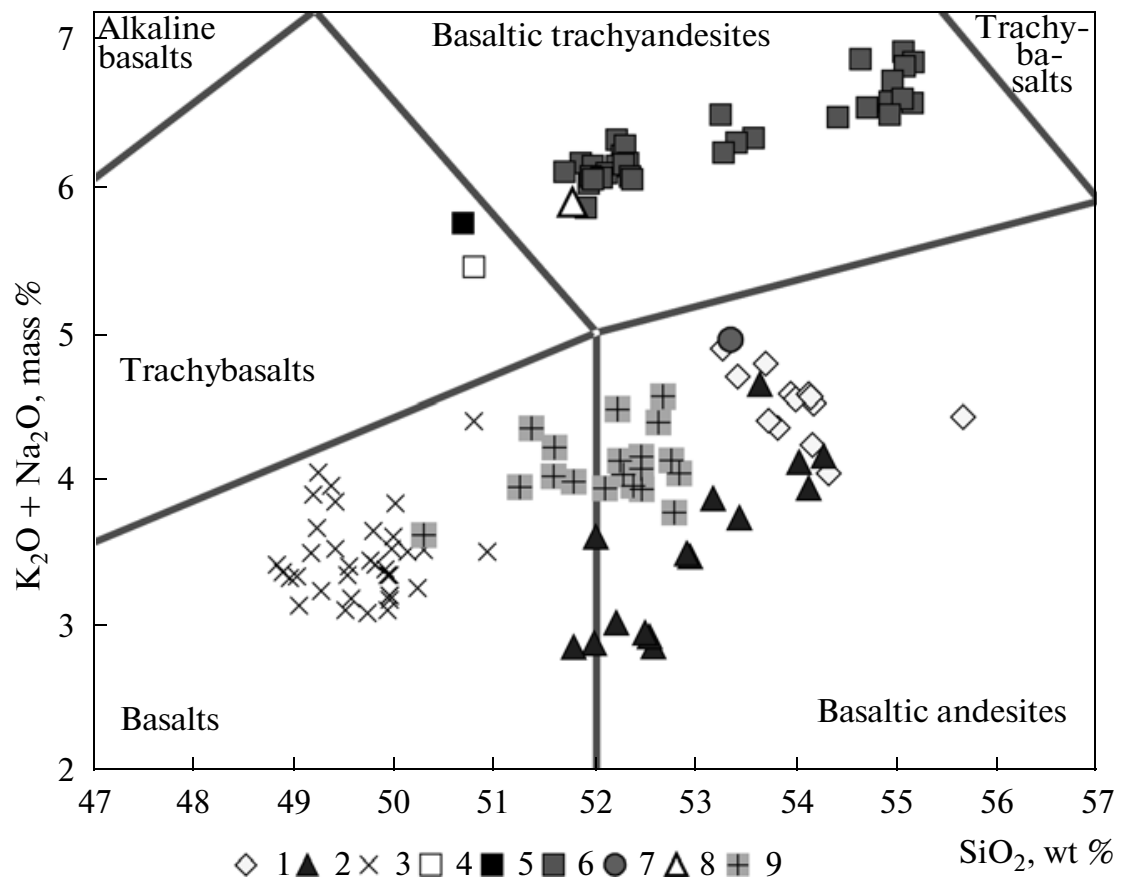

Fig. 4. Rock compositions for volcanoes in the Klyuchevskoi Cluster in a fragment of the $\mathrm{K}_{2} \mathrm{O}+\mathrm{Na}_{2} \mathrm{O}$ ) vs. $\mathrm{SiO}_{2}$ classification diagram (Petrograficheskii ..., 2009). Klyuchevskoi Volcano: (1) moderate potassium aluminiferous basaltic andesites; (2) moderate potassium magnesian basalts and basaltic andesites. Tolbachik Dol: (3) moderate potassium magnesian basalts, GTFE North Vent; $(4,5)$ average compositions of subalkaline aluminiferous basalt, GTFE South Vent (Bol'shoe ..., 1984). Ploskii Tolbachik Volcano: (6) K-high basaltic trachyandesites discharged by the 2012-2013 parasitic vent, (7) moderate potassium aluminiferous basaltic andesite from a geological section of the volcano (no. $974 \mathrm{GF}$ ); (8) K-high basaltic trachyandesites discharged by the 2012-2013 parasitic vent (Zelenski et al., 2014); (9) moderate potassium magnesian basalts and basaltic andesites from a geological section of Kharchinskii Volcano. 


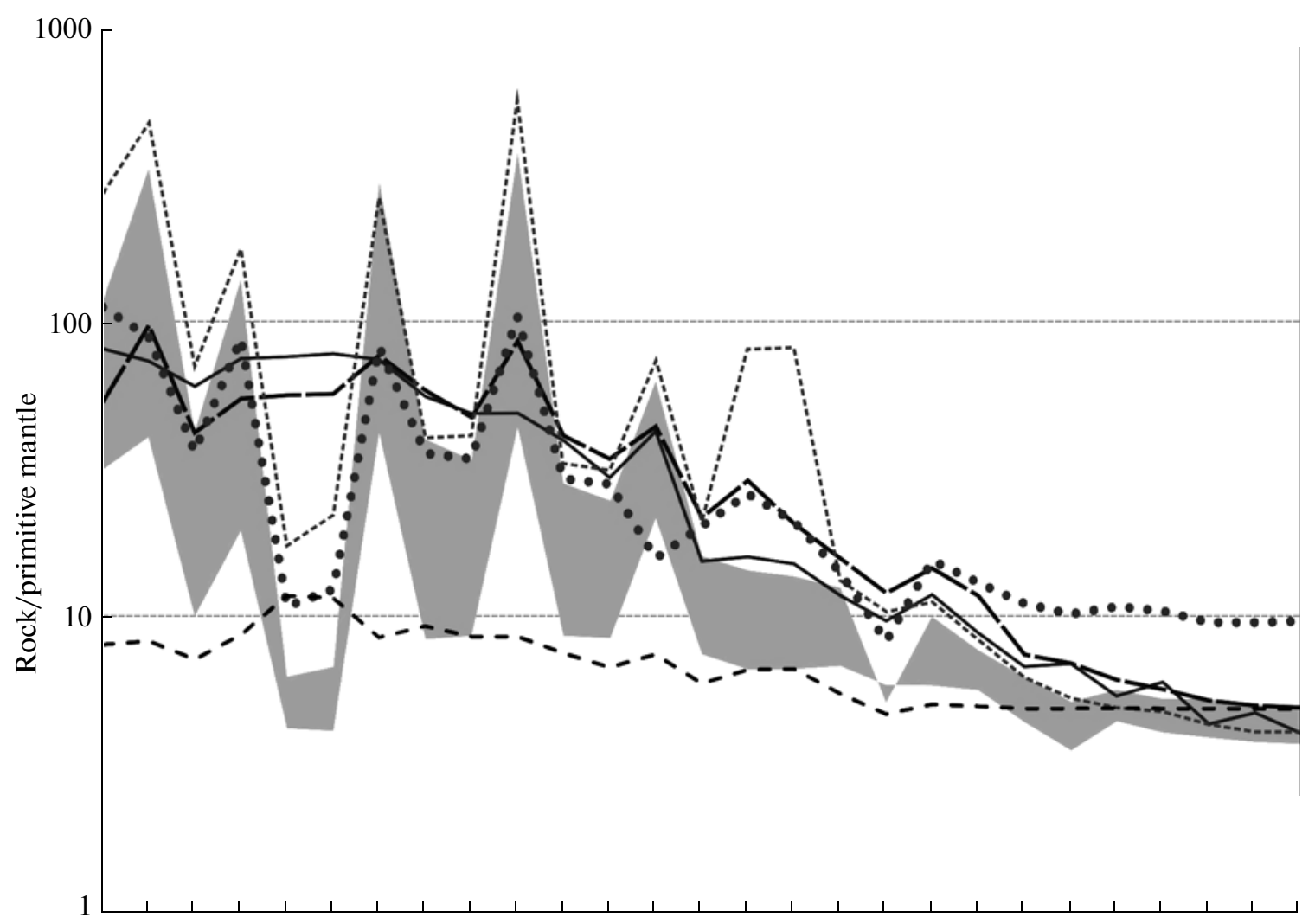

$\mathrm{Rb} \mathrm{Ba} T h \mathrm{U}$ Nb Ta K La Ce Pb Pr Nd Sr Sm Zr Hf Eu Ti Gd Tb Dy Ho Y Er Tm Yb Lu

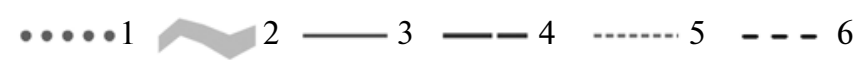

Fig. 5. Spider diagrams of riftogenic and intraplate basalts, basanites, and K-high basaltic trachyandesites discharged by the 2012-2013 parasitic vent on Ploskii Tolbachik Volcano.

(1) K-high basaltic trachyandesites discharged by the 2012-2013 parasitic vent on Ploskii Tolbachik; (2) field of shononite and latite compositions in western Kamchatka; (3) intraplate basanites in Mt. Khukhch, western Kamchatka; (4) hawaiites in western Kamchatka; (5) intraplate K-high basaltic trachyandesites in western Kamchatka; (6) E-MORB riftogenic trend after (Sun and McDonough, 1989). Results for compositions (2, 3, 4, 5) are from (Perepelov et al., 2007; Perepelov, 2014);

The concentrations of admixture elements in rocks $(\mathrm{g} / \mathrm{t}$ ) were normalized by their concentrations in undepleted mantle after (Sun and McDonough, 1989).

(see Table 1). The high concentrations of $\mathrm{K}_{2} \mathrm{O}$ in the 2012-2013 rocks make the data points of their compositions plot in the high potassium series field. These geochemical peculiarities in the basaltic trachyandesites that were discharged by the 2012-2013 parasitic eruption on Ploskii Tolbachik allow us to call them potassium-rich basaltic trachyandesites (K-high basaltic trachyandesites).

The distribution of incompatible elements in the $\mathrm{K}$-high basaltic trachyandesites in the spider diagram shows $\mathrm{Th}, \mathrm{Ce}$, and $\mathrm{Sr}$ minima, well-defined minima of high charge elements ( $\mathrm{Nb}, \mathrm{Ta}$, and $\mathrm{Ti}$ ), and $\mathrm{Rb}, \mathrm{U}$, and $\mathrm{Pb}$ maxima (Fig. 5).

The data points for basalts and basaltic andesites of Klyuchevskoi, Ploskii Tolbachik, and Kharchinskii volcanoes plot in the moderate potassium series field (see Fig. 4). The geochemical and mineralogic features of these rocks have been described in sufficient detail in the appropriate literature (Ermakov and Vazheevskaya, 1973; Khubunaya et al., 1993, 1998, 2007; Kersting and Arkulus, 1994; Ariskin et al., 1995; Volynets et al., 1999; Mironov, 2009, among others). All of these rocks possess similar petrographic characteristics, a similar list of rockforming minerals and their compositions, and similar concentrations of major elements and admixture elements (Table 2). The mineralogic features of these rocks distinguish them from most island-arc volcanic formations. All the moderate potassium magnesian and highsilica basalts and basaltic andesites contain high magnesium $\left(\mathrm{Fo}_{91-88}\right)$ olivines with high chrome spinel (see Fig. 3). The olivines are not in equilibrium with the chemical compositions of the rocks where they are found. At the same time, they can be in equilibrium in relation to the compositions of the parent mantle melts (Khubunaya et al., 1993, 2007). 
Table 2. Representative compositions of moderate potassium magnesian and aluminiferous basalts and basaltic andesites on volcanoes in the Klyuchevskoi Cluster and on Kharchinskii Volcano

\begin{tabular}{|c|c|c|c|c|c|c|}
\hline Oxides/no. & $11-3$ & $32-810 / 35$ & $57-826-77$ & $1-\mathrm{KL}$ & $974 \mathrm{GF}$ & $2023-103$ \\
\hline $\mathrm{SiO}_{2}$ & 51.98 & 52.90 & 54.11 & 54.13 & 54.33 & 52.77 \\
\hline $\mathrm{TiO}_{2}$ & 0.78 & 0.89 & 0.95 & 1.12 & 0.83 & 0.86 \\
\hline $\mathrm{Al}_{2} \mathrm{O}_{3}$ & 13.64 & 16.40 & 16.96 & 18.17 & 21.62 & 14.29 \\
\hline $\mathrm{FeO}$ & 8.47 & 8.24 & 8.32 & 8.58 & 8.67 & 8.60 \\
\hline $\mathrm{MnO}$ & 0.17 & 0.17 & 0.18 & 0.15 & 0.12 & 0.17 \\
\hline $\mathrm{MgO}$ & 11.00 & 7.54 & 5.82 & 4.51 & 2.04 & 9.90 \\
\hline $\mathrm{CaO}$ & 10.04 & 9.49 & 8.87 & 8.16 & 8.95 & 9.45 \\
\hline $\mathrm{Na}_{2} \mathrm{O}$ & 2.29 & 2.86 & 3.03 & 3.52 & 3.80 & 2.81 \\
\hline $\mathrm{K}_{2} \mathrm{O}$ & 0.59 & 0.64 & 0.92 & 1.05 & 1.15 & 0.97 \\
\hline $\mathrm{P}_{2} \mathrm{O}_{5}$ & 0.16 & 0.13 & 0.17 & 0.13 & 0.22 & 0.18 \\
\hline Total & 99.13 & 99.24 & 99.33 & 99.51 & 101.72 & 99.96 \\
\hline $\mathrm{Rb}$ & 9 & 10 & 15 & 16 & 14 & 15 \\
\hline $\mathrm{Ba}$ & 227 & 237 & 358 & 423 & 296 & 360 \\
\hline $\mathrm{Th}$ & 0.5 & 0.5 & 0.8 & 0.8 & 0.7 & 0.7 \\
\hline $\mathrm{U}$ & 0.3 & 0.3 & 0.4 & 0.4 & 0.5 & 0.4 \\
\hline $\mathrm{Nb}$ & 1.3 & 1.5 & 1.9 & 2.1 & 2.5 & 1.5 \\
\hline $\mathrm{Ta}$ & 0.09 & 0.11 & 0.13 & 0.14 & 0.16 & 0.10 \\
\hline$\hat{\mathrm{E}}$ & 4899 & 5313 & 7637 & 8716 & 9547 & 8052 \\
\hline $\mathrm{La}$ & 4.5 & 5.2 & 6.9 & 7.7 & 6.4 & 6.6 \\
\hline $\mathrm{Ce}$ & 10.8 & 12.2 & 16.0 & 17.3 & 16.2 & 15.5 \\
\hline $\mathrm{Pb}$ & 1.9 & 2.1 & 2.8 & 3.5 & 3.3 & 4.1 \\
\hline $\operatorname{Pr}$ & 1.7 & 2.0 & 2.5 & 2.7 & 2.5 & 2.4 \\
\hline $\mathrm{Nd}$ & 9.3 & 10.6 & 12.7 & 13.6 & 11.8 & 12.0 \\
\hline $\mathrm{Sr}$ & 239 & 301 & 358 & 367 & 418 & 432 \\
\hline $\mathrm{Sm}$ & 2.7 & 3.1 & 3.5 & 3.7 & 3.2 & 3.1 \\
\hline $\mathrm{Zr}$ & 69 & 82 & 91 & 95 & 89 & 72 \\
\hline $\mathrm{Hf}$ & 1.8 & 2.1 & 2.4 & 2.5 & 2.4 & 2.0 \\
\hline $\mathrm{Eu}$ & 0.87 & 1.01 & 1.15 & 1.33 & 1.13 & 1.1 \\
\hline $\mathrm{Ti}$ & 4675 & 5335 & 5694 & 6713 & 4975 & 5155 \\
\hline $\mathrm{Gd}$ & 2.9 & 3.3 & 3.6 & 4.0 & 3.5 & 3.1 \\
\hline $\mathrm{Tb}$ & 0.5 & 0.6 & 0.6 & 0.6 & 0.5 & 0.5 \\
\hline Dy & 3.4 & 3.9 & 4.1 & 4.5 & 3.3 & 3.1 \\
\hline Но & 0.7 & 0.8 & 0.9 & 0.9 & 0.7 & 0.6 \\
\hline$Y$ & 18 & 19 & 20 & 23 & 17 & 15 \\
\hline $\mathrm{Er}$ & 2.1 & 2.3 & 2.5 & 2.5 & 2.1 & 1.6 \\
\hline $\mathrm{Tm}$ & 0.29 & 0.33 & 0.36 & 0.34 & 0.28 & 0.23 \\
\hline $\mathrm{Yb}$ & 2.0 & 2.4 & 2.6 & 2.3 & 1.9 & 1.57 \\
\hline $\mathrm{Lu}$ & 0.30 & 0.34 & 0.38 & 0.37 & 0.29 & 0.22 \\
\hline $\mathrm{Ni}$ & 184 & 86 & 38 & 24 & 19 & 152 \\
\hline $\mathrm{Cu}$ & 71 & 70 & 92 & 101 & 112 & 107 \\
\hline $\mathrm{Zn}$ & 79 & 118 & 80 & 90 & 88 & 177 \\
\hline
\end{tabular}


Table 2. (Contd.)

\begin{tabular}{|c|c|c|c|c|c|c|}
\hline Oxides/no. & $11-3$ & $32-810 / 35$ & $57-826-77$ & $1-\mathrm{KL}$ & $974 \mathrm{GF}$ & 2023-103 \\
\hline $\mathrm{Sc}$ & 42 & 36 & 34 & 29 & 15 & 33 \\
\hline Co & 43 & 33 & 29 & 29 & 18 & 44 \\
\hline $\mathrm{Li}$ & 7 & 8 & 12 & 32 & 8 & 8 \\
\hline V & 242 & 231 & 267 & 265 & 199 & 237 \\
\hline $\mathrm{W}$ & 0.07 & 0.10 & 0.13 & 0.18 & 0.36 & 0.22 \\
\hline $\mathrm{Ba} / \mathrm{Nb}$ & 173 & 155 & 189 & 206 & 120 & 240 \\
\hline $\mathrm{Sr} / \mathrm{Nb}$ & 182 & 196 & 189 & 178 & 170 & 288 \\
\hline $\mathrm{Rb} / \mathrm{Ba}$ & 0.04 & 0.04 & 0.04 & 0.04 & 0.05 & 0.04 \\
\hline $\mathrm{Ta} / \mathrm{Yb}$ & 0.044 & 0.045 & 0.050 & 0.062 & 0.085 & 0.064 \\
\hline $\mathrm{Nb} / \mathrm{Yb}$ & 0.644 & 0.651 & 0.740 & 0.887 & 1.287 & 0.955 \\
\hline $\mathrm{La} / \mathrm{Yb}$ & 2.2 & 2.2 & 2.7 & 3.3 & 3.4 & 4.2 \\
\hline $87 \mathrm{Sr} / 86 \mathrm{Sr}$ & 0.70369 & 0.703589 & 0.70353 & 0.703664 & 0.70351 & 0.70352 \\
\hline $143 \mathrm{Nd} / 144 \mathrm{Nd}$ & 0.51282 & 0.513156 & 0.51316 & 0.513097 & 0.51309 & 0.51311 \\
\hline $206 \mathrm{~Pb} / 204 \mathrm{~Pb}$ & 18.30000 & 18.30100 & 18.2947 & 18.30690 & 18.23098 & 18.22710 \\
\hline $207 \mathrm{~Pb} / 204 \mathrm{~Pb}$ & 15.52200 & 15.54500 & 15.4958 & 15.48892 & 15.48169 & 15.45980 \\
\hline $208 \mathrm{~Pb} / 204 \mathrm{~Pb}$ & 38.04500 & 38.09200 & 37.9756 & 37.96904 & 37.92443 & 37.80310 \\
\hline
\end{tabular}

Klyuchevskoi Volcano: no. 11-3 is magnesian basalt from a lava flow discharged by unnamed cone; no. 32-810/35 is magnesian basaltic andesite from a volcanic bomb on explosive cone E; no. 57-826-77 is aluminiferous basaltic andesite from Nevidimka lava flow; no. 1-KL is aluminiferous basaltic andesite from a lava flow discharged by the 2008 summit eruption; no. 974 GF is aluminiferous basaltic andesite from a lava flow in a geological section of Ploskii Tolbachik Volcano. No. 2023-103 magnesian basaltic andesite from a lava flow in a geological section of Kharchinskii Volcano. Names of lava flows and cones on Klyuchevskoi Volcano are those in (Ermakov, 1977).

\section{THE ISOTOPE CHARACTERISTICS OF MODERATE POTASSIUM BASALTS, BASALTIC ANDESITES, AND K-HIGH BASALTIC TRACHYANDESITES: THE KLYUCHEVSKOI VOLCANIC CLUSTER}

The ratios among radiogenic isotopes provide one of the most important characteristics to describe the source of parent magmas. These ratios vary little during melting and during subsequent fractional crystallization in the magma chamber (Interpretatsiya ..., 2001). It is known that $\mathrm{Sr}, \mathrm{Nd}$, and $\mathrm{Pb}$ isotope ratios can also be used to evaluate the effects of the crust on the composition of the magma melt. Judging from ratios of radiogenic isotopes, the moderate potassium basalts and basaltic andesites of Klyuchevskoi and the K-high basaltic trachyandesites of Ploskii Tolbachik were generated in the mantle (Fig. 6). Another important feature in all the volcanic rocks that are considered here consists in the absence of any effects that the crust might possibly exert on the parent, moderate potassium, magnesian, high-silica, and high potassium melts (see Fig. 6). The Klyuchevskoi magnesian and high-silica basaltic andesites lie at the fractional crystallization line. Compared with moderate potassium basalts and basaltic andesites, the K-high basaltic trachyandesites exhibit lower ratios of radiogenic isotopes $\left({ }^{87} \mathrm{Sr} \mid{ }^{86} \mathrm{Sr}\right.$, ${ }^{143} \mathrm{Nd} /{ }^{144} \mathrm{Nd},{ }^{206} \mathrm{~Pb} /{ }^{204} \mathrm{~Pb}$ ) with higher concentrations of $\mathrm{Rb}$ and $\mathrm{Zr}$ (see Fig. 6).

\section{COMPARING K-HIGH BASALTIC TRACHYANDESITES WITH HIGH POTASSIUM ISLAND-ARC RIFTOGENIC AND INTRAPLATE IGNEOUS ROCKS}

According to the comparative method that is applied to the normalized distribution of incompatible elements based on the ratios between the concentrations of an element in the rock and its concentration in the primitive mantle, high potassium suprasubduction (island-arc) and $\mathrm{K}-\mathrm{Na}$ intraplate basanite and potassium trachybasaltic series of different ages were identified in Kamchatka (see Fig. 5) with well-pronounced geochemical and mineralogic signatures (Volynets, 1993; Volynets et al., 1990, 1995, 1997; Koloskov et al., 2011; Perepelov, 1989, 2014; Perepelov et al., 2003, 2005, 2006, 2007).

The K-high basaltic trachyandesites are similar to the Late Neogene intraplate $\mathrm{K}-\mathrm{Na}$ alkaline basaltoids of eastern Kamchatka, judging from the high concentrations of $\mathrm{Rb}$, this being one of the most incompatible light lithophile elements. The basaltoids have been identified by several investigators (Volynets et al., 1990, 1997; Perepelov et al., 2006, 2007, among others). At the same time, the K-high basaltic trachyandesites are sharply different from $\mathrm{K}-\mathrm{Na}$ alkaline and subalkaline volcanic rocks in having $\mathrm{Th}, \mathrm{Nb}, \mathrm{Ti}$, and $\mathrm{Ce}$ minima and higher concentrations of heavy REEs (see Fig. 6). In addition, intraplate $\mathrm{K}-\mathrm{Na}$ alkaline basaltoids of eastern Kamchatka have higher values of ${ }^{87} \mathrm{Sr} /{ }^{86} \mathrm{Sr}$ compared with island-arc lavas 

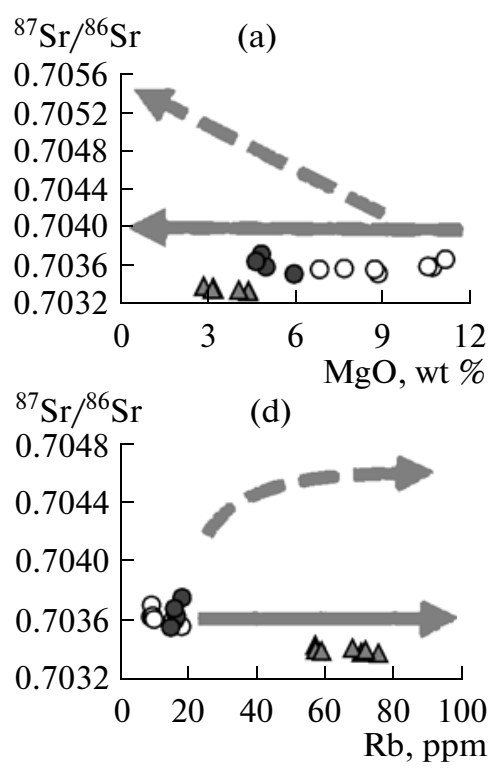

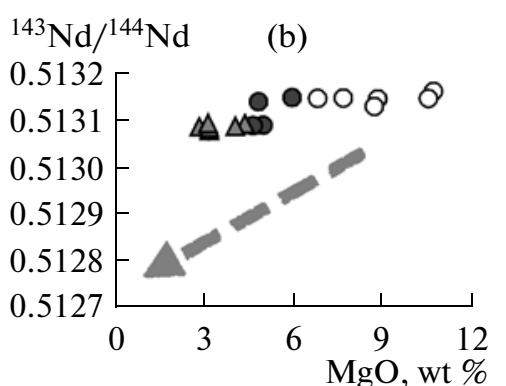

${ }^{87} \mathrm{Sr} /{ }^{86} \mathrm{Sr}$

0.7048

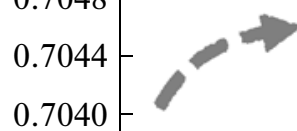

0.7036

0.7032

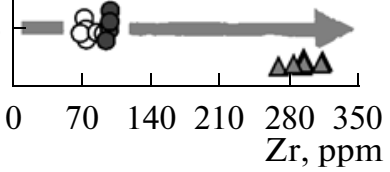

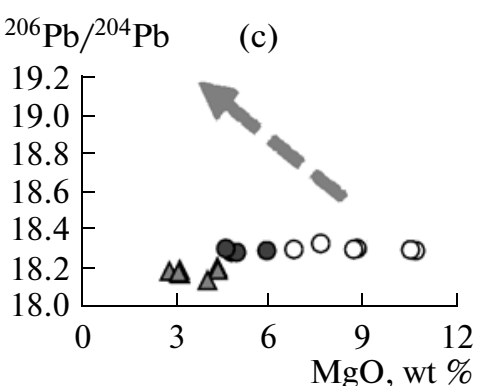

${ }^{87} \mathrm{Sr} /{ }^{86} \mathrm{Sr}$

(f)

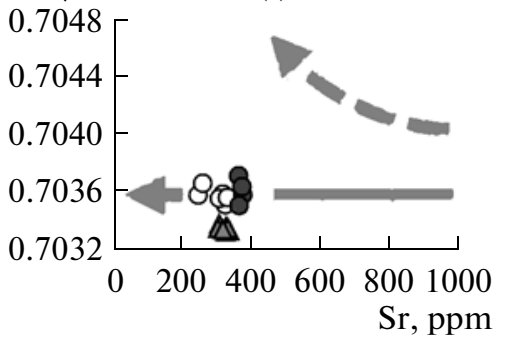

01

- $2 \Delta 3$

4

Fig. 6. Isotope characteristics of representative samples of basalts and basaltic andesites in the Klyuchevskoi Volcanic Cluster area. Klyuchevskoi: (1) magnesian basalts and basaltic andesites, (2) aluminiferous basaltic andesites, (3) K-high basaltic trachyandesites, Ploskii Tolbachik Volcano, (4) lines of fractional crystallization; (5) (a, b, c) line of crustal assimilation, Lesser Antilles; (5) (d, e, f) line of crustal assimilation, Salin Volcano. Notation 4 and 5 are from (Al'meev, 2005).

(Volynets et al., 1997). The K-high basaltic trachyandesites under consideration here exhibit lower ${ }^{87} \mathrm{Sr} /{ }^{86} \mathrm{Sr}$ ratios compared with island-arc lavas and lower values of that parameter compared with Late Neogene $\mathrm{K}-\mathrm{Na}$ alkaline basaltoids of eastern Kamchatka (see Fig. 6).

The K-high basaltic trachyandesites are similar to the Late Eocene to Early Oligocene, intraplate, K-high, alkaline basaltoids of eastern Kamchatka judging by the high concentrations of $\mathrm{U}$, as well as by the $\mathrm{Th}, \mathrm{Nb}-\mathrm{Ta}$, $\mathrm{La}-\mathrm{Ce}$, and Ti minima. The K-high basaltoids of western Kamchatka are different from the K-high basaltic trachyandesites that are considered here in having high degrees of differentiation, anomalously high concentrations of $\mathrm{K}, \mathrm{Pb}, \mathrm{Zr}$, and $\mathrm{Hf}$, a sharp deficit in $\mathrm{Rb}$ in relation to $\mathrm{Ba}$, as well as $\mathrm{Sr}$ maxima, and lower concentrations of heavy REEs as seen in spider diagrams (see Fig. 5). Considered in relation to these geochemical parameters, their data points in the spider diagrams are practically coincident with those for the Early to Late Miocene shoshonite-latite magmatism in western Kamchatka, while shoshonites, unlike the K-high basaltic trachyandesites, are characterized by anomalously low $\mathrm{Nb}-\mathrm{Ta}, \mathrm{La}-\mathrm{Ce}$, and $\mathrm{Pr}-\mathrm{Nd}$ minima and by lower concentrations of $\mathrm{Sm}$, $\mathrm{Zr}$, and $\mathrm{Hf}$. In addition, the K-high alkaline basaltoids have high magnesium numbers and high concentrations of $\mathrm{Ni}, \mathrm{Cr}$, and $\mathrm{Co}$. They typically contain high chromic spinel, Cr-diopside, and Cr-bearing phlogopite (Volynets et al., 1997; Perepelov, 2014, among others).
The K-high basaltic trachyandesites in multicomponent diagrams are very different from the intraplate basanites of western Kamchatka and from the hawaiites that occur in the Sredinnyi Mountain Range, Kamchatka in that they have $\mathrm{Nb}, \mathrm{Ta}$, and $\mathrm{Sr}$ minima, $\mathrm{Pb}$ maxima, greater concentrations of $\mathrm{Rb}$ compared with $\mathrm{Ba}$, and are strongly dominated by heavy REEs (see Fig. 5). In addition, the values of many marker rare-earth ratios in basanites and in K-high basaltic trachyandesites differ markedly. $\mathrm{The} \mathrm{Ba} / \mathrm{Nb}$ ratios in basanites are lower by ratios of 6 to 8 , while $\mathrm{Ta} / \mathrm{Yb}$ is an order greater than those in K-high basaltic trachyandesites: $\mathrm{Ba} / \mathrm{Nb}=10-12$ and $60-80, \mathrm{Ta} / \mathrm{Yb}=1.3-1.6$ and $0.11-0.13$, respectively (see Table 1). The basanites typically exhibit high concentrations of siderophile elements $(\mathrm{Co}, \mathrm{Ni}$, and $\mathrm{Cr}$ ), highcharge elements $(\mathrm{Nb}$ and $\mathrm{Ta})$, and radioactive elements (U) on the background of moderate concentrations of $\mathrm{Zr}$, $\mathrm{Hf}, \mathrm{Pb}, \mathrm{Cu}$, and $\mathrm{Sn}$ (Perepelov, 2014).

The high potassium basaltic andesites on Uksichan Volcano, which are the closest to K-high basaltic trachyandesites in silica content and in $\mathrm{K}_{2} \mathrm{O}$, show a sharp deficit of $\mathrm{Rb}(28 \mathrm{~g} / \mathrm{t})$ relative to $\mathrm{Ba}(850 \mathrm{~g} / \mathrm{t})$. This ratio is still lower in megaplagiophyre shoshonite-latite basalts of Tekletunup Volcano (Sredinnyi Range) and in the shoshonite basalts of western Kamchatka: Rb (46 and $88 \mathrm{~g} / \mathrm{t}$ ) and $\mathrm{Ba}(1520$ and $1100 \mathrm{~g} / \mathrm{t}$ ), respectively (Perepelov, 1989, Table 1). In contrast, the spider diagrams for K-high basaltic trachyandesites show a deficit in Ba relative to $\mathrm{Rb}$. In addition, the concentration of $\mathrm{TiO}_{2}$ in all high potas- 
sium basalts and basaltic andesites of Uksichan and Tekletunup is two times lower than that in K-high basaltic trachyandesites $(0.89 \%, 1 \%$, and $2 \%$, respectively).

Our comparative analysis of normalized distributions of concentrations of incompatible elements in K-high basaltic trachyandesites and in intraplate rocks in relation to the ratios of their concentrations to those in the primitive mantle showed that they are due to different sources. The K-high basaltic trachyandesites belong to neither of the different-age, intraplate, high potassium series or the $\mathrm{K}-\mathrm{Na}$ series in Kamchatka. At the same time, they were discharged during Holocene time in the immediate vicinity of suprasubduction moderate potassium basalts and basaltic andesites of Klyuchevskoi, Ploskii Tolbachik (the 1941 eruption), and Tolbachik Dol (the North Vent of the GTFE, 1975). Comparison of geochemical features that are present in K-high basaltic trachyandesites with those of suprasubduction moderate potassium basalts and basaltic andesites in the Klyuchevskoi Volcanic Cluster could help toward clarifying their formational affiliation.

\section{COMPARISON OF K-HIGH BASALTIC TRACHYANDESITES WITH MODERATE POTASSIUM SUPRASUBDUCTION BASALTS AND BASALTIC ANDESITES}

All calc-alkaline moderate potassium magnesian and high-alumina basalts and basaltic andesites in the Klyuchevskoi Volcanic Cluster exhibit similar configurations of data points for all admixture elements in the multicomponent diagram showing distributions of incompatible elements (Fig. 7). The spider diagrams for these rocks show deep minima of high-charge elements ( $\mathrm{Th}, \mathrm{Nb}$, and Ti) and maxima of large ion lithophile elements (Ba, K, $\mathrm{Sr}$, and $\mathrm{Pb}$ ), as well as of $\mathrm{U}$. Similar distributions of admixture elements are typical of the rocks that belong to the moderate potassium suprasubduction series in Kamchatka. A well-pronounced $\mathrm{Sr}$ minimum occurs in all moderate potassium rocks, both in basalts with the highest $\mathrm{Mg} \#$ and high-alumina basalts and basaltic andesites on Klyuchevskoi Volcano, as well as for the high-alumina basaltic andesites of Ploskii Tolbachik (see Fig. 7). Similar distributions of $\mathrm{Sr}$ are also typical of all island-arc volcanic rocks (Holm, 1985; Volynets et al., 1999, among others). This typical geochemistry of moderate potassium islandarc magmas is commonly described in the framework of mobilistic theory as the mixing of two independent components that characterize the sources of these magmas: a strongly depleted "dry" material (the mantle wedge beneath the island arc above a subduction zone) and a component that resulted either from melting of island arc magma or from dehydration of the subducted plate. The process as described can furnish the bulk of elements with large ion radii and water (Pearce et al., 2005). This is also supported by experimental evidence (Tatsumi et al., 1994). The geochemistry of the moderate potassium vol- canic rocks that are studied here is in general agreement with the above model. One finds an obvious discrepancy in the relationship between $\mathrm{Rb}$ and $\mathrm{Ba}$, viz., a deficit of $\mathrm{Rb}$ relative to $\mathrm{Ba}$, as observed in the spider diagrams for all moderate potassium island arc basalts (see Fig. 7). This circumstance suggests that the mantle residue must contain a phase with $\mathrm{Rb}$, apparently phlogopite (Khubunaya and Sobolev, 1998). A model was proposed for melting of an undepleted mantle source of the lherzolite-harzburgite series to explain the origin of the parent melts of the Klyuchevskoi moderate potassium magnesian basalts, with the melting being due to the water-bearing component of the subducted plate (Khubunaya and Sobolev, 1998). The results that were obtained here suggest that the melt separated from the mantle material at depths of 50$60 \mathrm{~km}$ (Khubunaya et al., 2007).

The geochemical and mineralogic features of the moderate potassium magnesian basalts that were discharged by Klyuchevskoi, Ploskii Tolbachik (the 1941 eruption), and in the Tolbachik Dol (the GTFE North Vent) are similar, thus suggesting a common mantle source. This inference is not contradicted by recent geophysical research. We may invoke the movement of parent moderate potassium magnesian melts for considerable distances (as far as for $100 \mathrm{~km}$ ) from a peripheral chamber beneath Klyuchevskoi Volcano (Fedotov et al., 2014) to explain present-day eruptions of moderate potassium magnesian basalts beneath Ploskii Tolbachik and the Tolbachik Dol. At the same time, moderate potassium high magnesium basalts and their differentiates were numerically modeled by the least-squares method (Wright and Doherty, 1970). The modeling showed that fractional crystallization of $\mathrm{Ol}$ and $\mathrm{Cpx}$ can produce moderate potassium magnesian basalt from a parent moderate potassium high-magnesium basaltic melt (Khubunaya et al., 1993). K-high basaltic trachyandesites cannot be obtained by fractional crystallization from parent moderate potassium high magnesium melts. They must have an independent source of their own.

\section{THE FORMATIONAL AFFILIATION OF K-HIGH BASALTIC TRACHYANDESITES}

The geochemical features of K-high basaltic trachyandesites that are considered here suggest that their source is most likely to be similar to the mantle suprasubduction source of the island-arc moderate potassium basaltic series. This is primarily indicated by the similarities between the plots of the data points in the spider diagram (see Fig. 7). Similarly to the moderate potassium basaltoids of the Klyuchevskoi Volcanic Cluster and of Kharchinskii Volcano, the K-high basaltic trachyandesites are characterized by typical geochemical features of suprasubduction moderate potassium magmas: welldefined minima of high-charge elements ( $\mathrm{Ti}, \mathrm{Nb}, \mathrm{Ta}$, and $\mathrm{Th}$ ) and by Ce minima, as well as by clear $\mathrm{U}, \mathrm{K}$, and $\mathrm{Pb}$ 


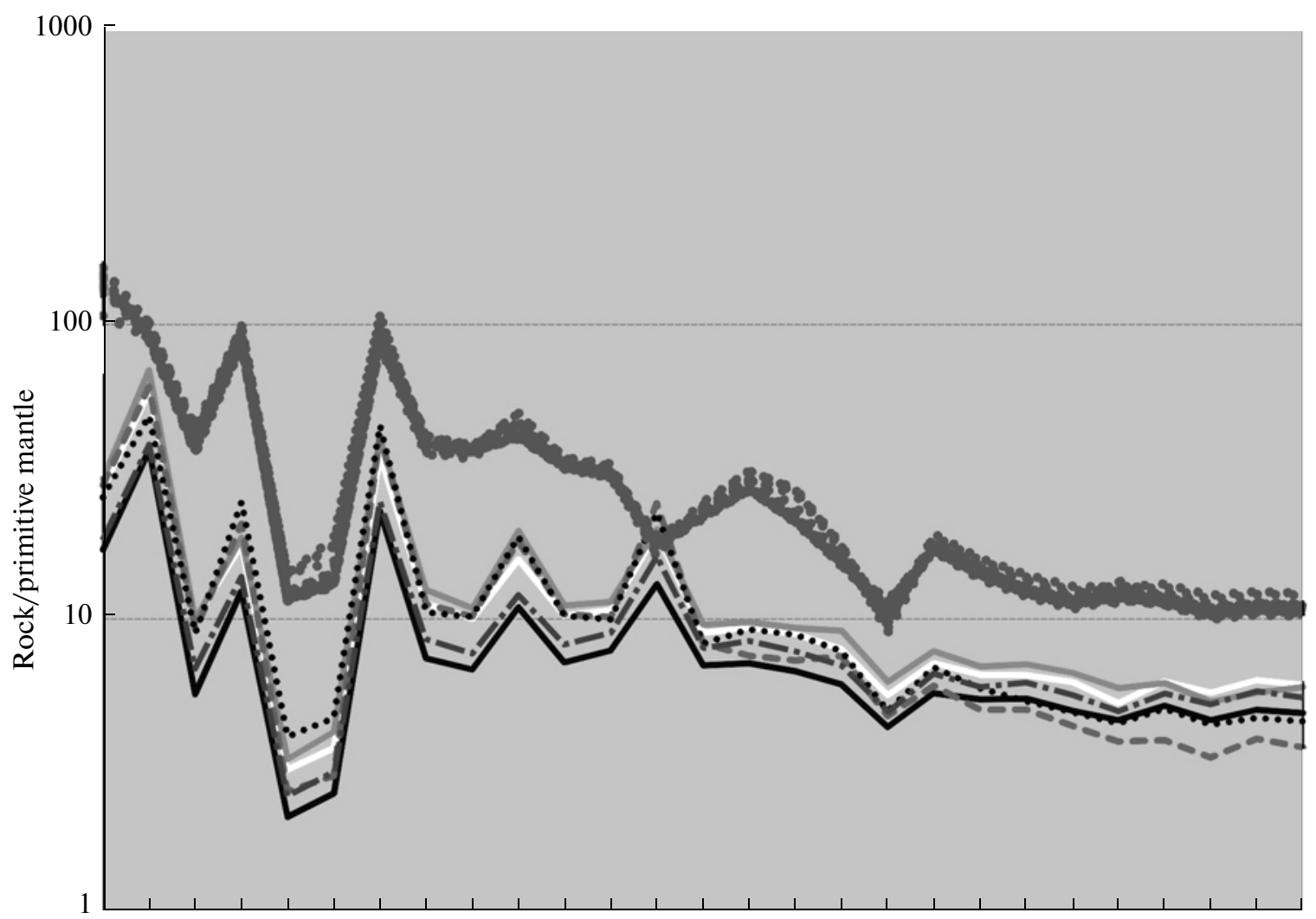

$\mathrm{Rb} \mathrm{Ba}$ Th U Nb Ta K La Ce Pb Pr Nd Sr Sm Zr Hf Eu Ti Gd Tb Dy Ho Y Er Tm Yb Lu

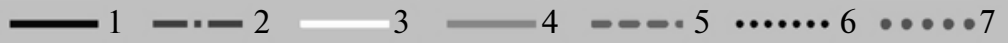

Fig. 7. Spider diagrams of K-high basaltic trachyandesites, moderate potassium basalts and basaltic andesites.

Klyuchevskoi Volcano: (1) magnesian basalt in a lava flow discharged from unnamed cone (no. 11-3); (2) magnesian basaltic andesite in a volcanic bomb discharged from explosive cone E (32-810/35); (3) aluminiferous basaltic andesite from the Nevidimka lava flow (no. 57-826-76); (4) aluminiferous basaltic andesite from a lava flow discharged by the summit eruption of 2008 (no. 1-KL); (5) magnesian basaltic andesite from a lava flow in a geological section of Kharchinskii Volcano (2023-104).

Ploskii Tolbachik Volcano: (6) aluminiferous basaltic andesite from a lava flow in a geological section of the volcano (974 GF); (7) K-high basaltic trachyandesites discharged by the 2012-2013 parasitic vent. The concentrations of admixture elements in rocks were normalized by their concentrations in primitive mantle after (Hoffman, 1988). Cone names on Klyuchevskoi are those in (Ermakov, 1977).

maxima. The points for heavy REEs in K-high basaltic trachyandesites and moderate potassium basalts and basaltic andesites, from $\mathrm{Gd}$ to $\mathrm{Lu}$, form parallel plots. All these issues provide evidence of similar compositions for the mantle sources of the rocks that we are comparing.

The main differences in the distribution of incompatible elements in the spider diagrams of moderate potassium basaltoids and K-high basaltic trachyandesites involve $\mathrm{Rb}$ maxima, $\mathrm{Sr}$ minima, and higher concentrations of all incompatible elements in the latter (see Fig. 7). Geochemical-formation analysis is based on the ratios of the average concentrations of incompatible elements in rocks to the concentrations of these elements in the primitive mantle (normalized ratios) (Wood, 1979). Petrographic, mineralogic, and geochemical analysis of $\mathrm{K}$-high basaltic trachyandesites is a better guide to evaluation of their formational affiliation. One important chemical element in formational analysis of this kind is $\mathrm{Sr}$ (Holm, 1985; Volynets et al., 1995, among others). It is known that plagioclase is the main concentrator of $\mathrm{Sr}$ in the magmatic process. The $\mathrm{Sr}-$ plagioclase partition coefficients are very high. They are 2.2 for basic melts and 4.4 for intermediate and acid melts (Cox et al., 1979, p. 142). Plagioclase is known to be affected by crystallization gravitational differentiation in intermediate magma chambers. This must be taken into account in classifying $\mathrm{K}$-high basaltic trachyandesites as belonging to a particular geochemical formation, along with the data including the concentration of $\mathrm{Sr}$ in these rocks, among other factors. The isotope characteristics of $\mathrm{Pb}, \mathrm{Nd}$, and $\mathrm{Sr}$ in the K-high basaltic trachyandesites provide evidence of their mantle genesis. They are low magnesium volcanic rocks (see Table 1). The compositions of phenocrysts of the olivine with the highest magnesium number $\left(\mathrm{Fo}_{83-72}\right)$ are 
not ones that can be in equilibrium with mantle melting of $\mathrm{Fo}_{89-92}$ (Lee Cin-Ty et al., 2009). K-high basaltic trachyandesites are essentially deeply differentiated subaphyric volcanic formations. Their petrographic, mineralogic, and geochemical features suggest a considerable fractional crystallization of plagioclase in a shallow (1-2 km) magma chamber beneath Ploskii Tolbachik Volcano. The location of the intermediate magma chamber is based on the seismological results (Ermakov et al., 2014). Plagioclase can undergo fractional crystallization via degassing of water at low pressures in the shallow intermediate chamber or due to a lower original concentration of water in the K-high basaltic trachyandesite melt compared with the concentration of water $(3-3.5 \%)$ in the parental melts of moderate potassium magnesian basalts (Khubunaya and Sobolev, 1998; Mironov and Portnyagin, 2011, among others). Large plagioclase phenocrysts and plagioclase growths could accumulate on the bottom of the shallow magma chamber and make plagioclase cumulates (see Figs. 2e and 2f). The residual melt in the apical part of the chamber could be depleted in Sr during the process. The fact that the Pl may be jigged is indicated by $\mathrm{Sr}$ minima in the spider diagrams of K-high basaltic trachyandesites and the non-uniform distribution of large plagioclase phenocrysts in ascending magma (see Fig. 2b). The apical part of the shallow intermediate chamber was depleted in plagioclase crystals. Plagioclase jigging might occur, as indicated by large crystal lapilli (plagioclase lamellae and growths) that were erupted together with cinder lapilli of K-high basaltic trachyandesites (see Figs. 2b, 2c, and 2d). Some support can also come from plagioclase cumulates (see Figs. 2e and $2 \mathrm{f})$. These cumulative plagioclase formations occur as xenoliths in volcanic bombs in the material that erupted at the GTFE North Vent, Lavovyi Shish, Ploskaya Dal'nyaya Volcano, as well as eruptions in other areas where K-high basaltic trachyandesites or megaplagiophyric basalts were erupted (Figs. 2e, 2f). No xenoliths of plagioclase cumulates were present in the ejecta of Klyuchevskoi, Bezymyannyi, and Shiveluch volcanoes where no K-high basaltic trachyandesites or megaplagiophyric basalt were erupted. Based on the above argument, it may be conjectured that the parental high-alumina melt of K-high basaltic trachyandesites was enriched in $\mathrm{Sr}$ and the associated spider diagrams might involve an $\mathrm{Sr}$ maximum, similarly to all other suprasubduction basalts and basaltic andesites.

One of the chief geochemical features in K-high basaltic trachyandesites consists in high concentrations of $\mathrm{Rb}$. The spider diagrams for these rocks show an Rb maximum. High concentrations of $\mathrm{Rb}$ in the K-high basaltic trachyandesites, high $\mathrm{Rb} / \mathrm{Ba}$ ratios that are nearly an order of magnitude above those for the moderate potassium rocks, all provide evidence that the melting mantle substratum must contain a phase with $\mathrm{Rb}$; this phase seems to be phlogopite (see Tables 1 and 2). It is known that phlogopite, in the absence of amphibole, is the most likely accumulator, not only of $\mathrm{Rb}$, but also of $\mathrm{K}$ and $\mathrm{H}_{2} \mathrm{O}$ (Cox et al., 1979). It is probable that a complete decomposition of phlogopite by the action of fluids during the dehydration of the subducted plate led to melting of the deep-seated suprasubduction source of K-high basaltic trachyandesites. The source was deeper than the source of moderate potassium rocks (Khubunaya and Sobolev, 1998). Phlogopite is known to be stable in the upper mantle up to pressures of 35 kbars (Bravo and O'Hara, 1975). In addition, the mantle source of K-high basaltic trachyandesites seems to have experienced partial melting to a lesser extent compared with the source of moderate potassium rocks. The $\mathrm{Nb} / \mathrm{Yb}$ ratios in $\mathrm{K}$-high basaltic trachyandesites are two times higher compared to those in moderate potassium basalts and basaltic andesites (see Tables 1 and 2).

Increased concentrations of all incompatible elements in the K-high basaltic trachyandesites compared with moderate potassium rocks are probably related to considerable fractional crystallization of plagioclase in the melt of the shallow magma chamber. The higher concentrations of incompatible elements in the K-high basaltic trachyandesites were also caused by enrichment of the parental melts in fluids that contained incompatible elements during the dehydration of the subducted plate (Tatsumi et al., 1994).

The eruption of K-high basaltic trachyandesites on the southern slope of Ploskii Tolbachik Volcano and the distributions of incompatible elements in them as described here could have been caused by melting at a suprasubduction mantle source that was deeper than the source of moderate potassium rocks. The latter source seems to have experienced a lesser degree of melting. The depth of melting at the source of K-high basaltic trachyandesites is limited to the depth of phlogopite decomposition. It has been shown (Khubunaya and Sobolev, 1998; Khubunaya et al., 2007) that melting at the source of moderate potassium suprasubduction magnesian basalts occurs at a depth of $50-60 \mathrm{~km}$. The deeper (up to $100-110 \mathrm{~km}$ ) melting at the source of K-high basaltic trachyandesites provides evidence of a heterogeneous mantle and different melting depths at the mantle sources of the rocks under comparison.

\section{A HYPOTHETICAL PROCESS FOR THE PRODUCTION OF K-HIGH BASALTIC TRACHYANDESITES}

The petrographic, mineralogic, and geochemical features of K-high basaltic trachyandesites suggest a twostage fractional crystallization of the parental original melt in intermediate magma chambers beneath Ploskii Tolbachik Volcano (Fig. 8). The first stage might involve the crystallization of high magnesium olivine and pyroxene from a magnesian melt in the presence of $\mathrm{H}_{2} \mathrm{O}$ at a 
depth of $15-20 \mathrm{~km}$ in an intermediate magma chamber (Ermakov et al., 2014), with the field of plagioclase crystallization being considerably restricted during this process. The residual melt was enriched in aluminum oxide and alkalies and depleted in magnesium and iron. That fact that such a crystallization of a basaltic melt in the presence of water is possible was shown experimentally by Green and Ringwood (1968). Unfortunately, there is no evidence to indicate the compositions of high magnesium minerals that might crystallize during the first stage in the deeper magma chamber (see Fig. 8). At the same time, the 26 incompatible elements that were found to be present in K-high basaltic trachyandesites characterize, not only their geochemical features, but also the geochemical features of their parental (primary) melts. Incompatible elements that were present in this magmatic process do not possess concentrator minerals (apart from plagioclase) and the subsequent fractional crystallization in the deeper magma chamber did little to affect the concentrations of incompatible elements in the melt.

The subsequent fractional crystallization of plagioclase from the residual high-alumina melt could have occurred at a depth of $1-2 \mathrm{~km}$ in the shallow magma chamber (see Fig. 8). The residual melt in the apical part of the shallow intermediate magma chamber was undergoing plagioclase depletion. This is directly corroborated by the $\mathrm{S}$ minima that are observable in the spider diagrams of K-high basaltic trachyandesites, as well as by the fractional crystallization of plagioclase in the shallow magma chamber as described above.

The geochemical features of the K-high basaltic trachyandesites that are considered here suggest that they can be classified as belonging to the suprasubduction subalkaline series of the potassium series.

\section{CONCLUSIONS}

The present study of the petrographic, mineralogic, and geochemical features that were discoverable in K-high basaltic trachyandesites showed that these rocks exhibit obvious signs of a suprasubduction origin. They are deeply differentiated rocks that are characterized by considerable fractionation of $\mathrm{Pl}$ and probably by degassing of $\mathrm{H}_{2} \mathrm{O}$ in the shallow chamber.

At the same time, the study of radiogenic isotope characteristics for $\mathrm{Pb}, \mathrm{Sr}$, and $\mathrm{Nd}$ for K-high basaltic trachyandesites provides evidence of a mantle origin and indicates that there was no crustal effect on their compositions.

A comparative analysis of normalized distributions of incompatible elements in K-high basaltic trachyandesites and of those for moderate potassium intraplate, riftogenic, and suprasubduction basalts and basaltic andesites showed that the source of K-high basaltic trachyandesites is the closest to that of moderate potassium suprasubduction basaltoids.

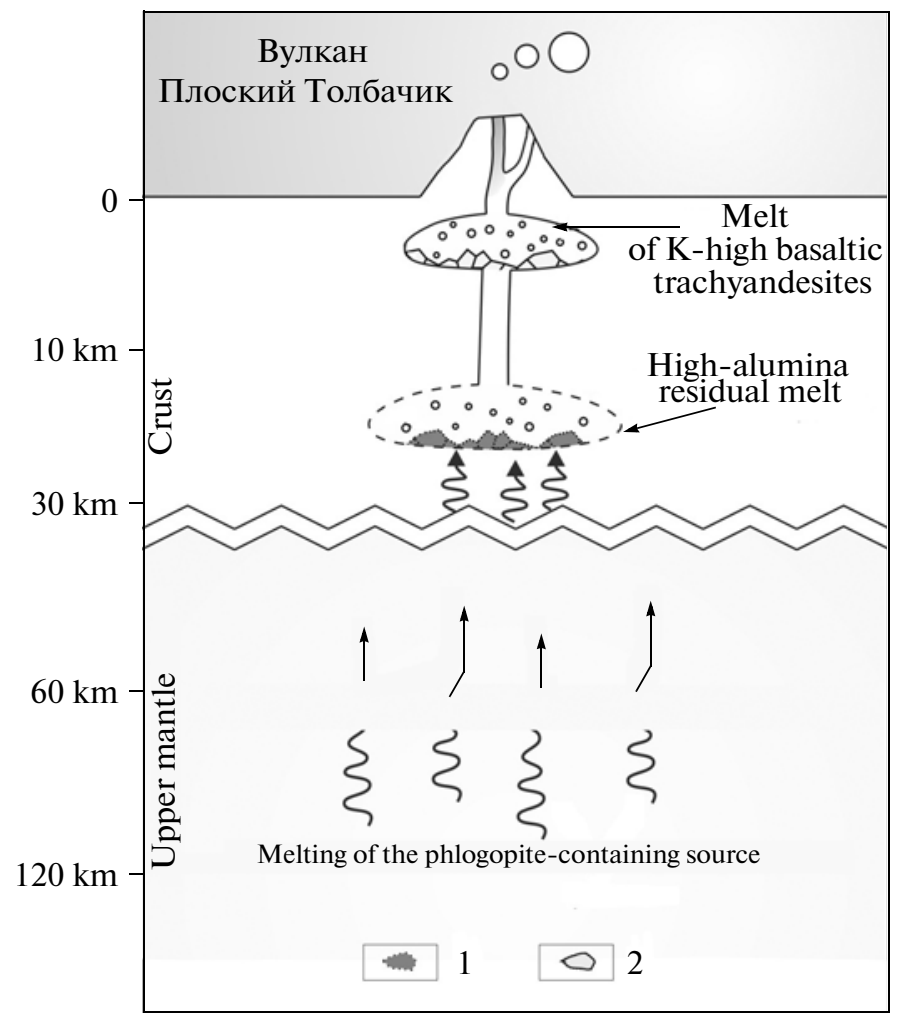

Fig. 8. Hypothetical model for the generation of the Khigh basaltic trachyandesites discharged by the 2012-2013 parasitic eruption on Ploskii Tolbachik (TFE-50).

(1) High magnesium olivines and clinopyroxenes; (2) plagioclase cumulates.

The leading distinctions in the distribution of incompatible elements between basaltoids and K-high basaltic trachyandesites consist in higher $\mathrm{Nb} / \mathrm{Yb}$ and $\mathrm{Rb} / \mathrm{Ba}$ ratios, in $\mathrm{Rb}$ maxima, $\mathrm{Sr}$ minima, and in higher concentrations of all incompatible elements in the latter rocks.

The $\mathrm{S}$ minima in the spider diagrams of K-high basaltic trachyandesites are probably related to fractional crystallization of plagioclase.

The enrichment of the source of K-high basaltic trachyandesites in incompatible elements was due to fractional crystallization of plagioclase and the supply of incompatible admixture elements due to the dehydration of the subducted plate.

The geochemical features of K-high basaltic trachyandesites and moderate potassium island-arc basalts and basaltic andesites as discussed here furnish evidence of different melting depths for the mantle sources of the rocks being compared.

The geochemical features of K-high basaltic trachyandesites suggest their affiliation with the subalkaline suprasubduction formation of the potassium series. 


\section{ACKNOWLEDGMENTS}

We wish to thank Academician S.A. Fedotov and Academician E.I. Gordeev; P.A. Izbekov, who is Researcher at the Volcano Observatory, University of Alaska, Fairbanks; Senior Researcher, Cand. Sci. (Geol.-Mineral.) G.B. Flerov, Senior Researcher, Cand. Sci. (Geol.-Mineral.) A.O. Volynets for the materials they gave us, and Head of the Laboratory of Dynamic Volcanology, Dr. Sci. (Geol.-Mineral.) I.V. Melekestsev, Leading Researcher, Cand. Sci. (Geol.-Mineral.) L.I. Gontovaya, and Dr. Sci. (Geol.-Mineral.) Yu.A. Kostitsyn for helpful discussions.

Our study would have been impossible to carry out without the help that was provided by Leading Programmer I.M. Romanova, Senior Researcher V.N. Dvigalo, Researcher V.V. Anan'ev, Leading Engineer S.V. Moskaleva, Senior Engineer V.V. Pantileeva, Engineer V.S. Khubunaya, and Engineer A.V. Sokorenko. The authors wish to express their sincere gratitude to all the colleagues at the Institute of Volcanology and Seismology listed above, as well as to heads of the field teams A.B. Belousov, D.P. Savel'ev, and Yu.V. Demyanchuk, and to Deputy Director of the Institute of Volcanology and Seismology Ya.D. Murav'ev.

This work was supported by the Russian Foundation for Basic Research, project no. 13-05-12090.

\section{REFERENCES}

Al'meev, R.R., The Geochemistry of Magmatism for Bezymyannyi Volcano: Evidence for a Mantle Source and the Conditions for Fractionation of Parental Magma, Extended Abstract of Cand. Sci. (Geol.-Mineral.) Dissertation, Moscow, 2005.

Ariskin, A.A., Barmina, G.S., Ozerov, A.Yu., and Nil'sen, R.L., The genesis of high alumina basalts of Klyuchevskoi Volcano, Petrologiya, 1995, vol. 3, no. 5, pp. 496-521.

Berzina, A.P., Berzina, A.N., Gimon, V.O., et al., The Shakhtaminskii porphyry Mo ore-magmatic system, eastern Transbaikalia: Age, sources, genetic features, Geologiya $i$ Geofizika, 2013, vol. 54, no. 6, pp. 764-786.

Bol'shoe treshchinnoe Tolbachinskoe izverzhenie, 19751976 gg., Kamchatka (The Great Tolbachik Fissure Eruption, 1975-1976, Kamchatka), Fedotov, S.A., Ed., Moscow: Nauka, 1984.

Bravo, M.S. and O'Hara, M.J., Partial melting of phlogopite-bearing synthetic spinel and garnet lherzolites, Phys. Chem. Earth., 1975, vol. 9, pp. 845-854.

Cox, K.G., Bell, J.D., and Pankhurst, R.J., The Interpretation of Igneous Rocks, Springer, 1979.

Dvigalo, V.N., Svirid, I.Yu., and Shevchenko, A.V., The first quantitative estimates of parameters for the Tolbachik Fissure

Eruption of 2012-2013 from aerophotogrammetric observations, J. Volcanol. Seismol., 2014, vol. 8, no. 5, pp. 261268.

1 Ermakov, V.A., Formatsionnoe raschlenenie chetvertichnykh vulkanicheskikh porod (Formation Classification of Quaternary Volcanic Rocks), Moscow: Nedra, 1977.
Ermakov, V.A. and Vazheevskaya, A.A., Ostryi and Ploskii Tolbachik volcanoes, Byull. Vulkanol. St., no. 49, Novosibirsk: Nauka, 1973, pp. 43-53.

Ermakov, V.A., Gontovaya, L.I., and Senyukov, S.L., Tectonic setting and magma sources of the recent Tolbachik fissure eruption, Kamchatka Peninsula, in Geofizicheskie protsessy i biosfera (Geophysical Processes and the Biosphere), 2014, vol. 13, no. 1, pp. 5-33.

Fedotov, S.A., Slavina, L.B., Senyukov, S.L., and Kuchai, M.S., Seismic processes and magma movements during the 19751976 Great Tolbachik Fissure Eruption and during the 2012-2013 Tolbachik Fissure Eruption, Kamchatka Peninsula, in Geofizicheskie protsessy i biosfera (Geophysical Processes and the Biosphere), 2014, vol. 13, no. 3, pp. 5-30.

Flower, M.F., Mantle extrusion: a model for dispersed volcanism and DUPAL-like asthenosphere in East Asia and the West Pacific, in Mantle Dynamics and Plate Interactions in East Asia, Flower, M.F., Tamaki, K., and Hoang, N., Eds., Geodynamics, 1998, no. 27, pp. 67-85.

Gill, J.B., Geochemistry of Viti Levu, Fiji, and its evolution as an island arc, Contr. Mineral. Petrol., 1970, vol. 27. pp.179-203.

Gordeev, E.I., Murav'ev, Ya.D., Samoilenko, S.B., et al., The 2012-2013 Tolbachik Fissure Eruption. First results, Dokl. Akad. Nauk, 2013, vol. 452, no. 5, pp. 562-566.

Gordeev, E.I., Karpov, G.A., Anikin, L.P., et al., Diamonds in the lavas of the Tolbachik Fissure Eruption, Kamchatka, Dokl. Akad. Nauk, 2014, vol. 454, no. 2, pp. 204-206.

Green, D.H. and Ringwood, A.E., Genesis of calc-alkaline igneous rocks suite, Contr. Mineral. Petrol., 1968, vol. 18, no. 2, pp. 105-162.

Hofmann, A.W., Chemical differentiation of the Earth: the relationship between mantle, continental crust, and oceanic crust, Earth Planet. Sci. Lett., 1988, vol. 90, pp. 297-314.

Holm, P.E., The geochemical fingerprints of different tectonomagmatic environments using hydromagmatophile element abundances of tholeiitic basalts and basaltic andesites, Chem. Geol., 1985, vol. 51, nos.3-4, pp. 303-323.

Interpretatsiya geokhimicheskikh dannykh (Interpretation of Geochemical Data), Sklyarov, E.V., Ed., Moscow: Intermet Inzhiniring, 2001.

Karandashev, V.K., Turanov, A.N., Orlova, T.A., et al., Use of the inductively coupled plasma mass spectrometry for element analysis of environmental objects, Inorg. Mater., 2008, vol. 44, pp. 1491-1500.

Kersting, A.B. and Arculus, R.J., Klyuchevskoy Volcano, Kamchatka, Russia: The role of high-flux recharged, tapped and fractionated magma chamber(s) in the genesis of high- $\mathrm{A}_{2} \mathrm{O}_{3}$ from high-MgO basalt, J. Petrol., 1994, vol. 35 , no. 1 , pp. 1-41.

Khanchuk, A.I. and Ivanov, V.V., Mesozoic to Cenozoic geodynamic settings and gold mineralization in the Russian Far East, Geologiya i Geofizika, 1999, vol. 40, no. 11, pp. 1635-1645.

Khubunaya, S.A., Bogoyavlenskii, S.O., Novgorodtseva, T.Yu., and Okrugina, A.M., The mineralogy of the Klyuchevskoi magnesian basalts depicting the fractionation in the magma chamber, Volcanology and Seismology, 1993, vol. 15 , no. 3 , pp. 315-338.

Khubunaya, S.A. and Sobolev, A.V., Primary melts of calcalkaline magnesian basalts: Klyuchevskoi Volcano, Kamchatka, Dokl. Akad. Nauk, 1998, vol. 360, no. 1, pp. 100102.

Khubunaya, S.A., Gontovaya, L.I., Sobolev, A.I., and Nizkous, I.V., Magma chambers beneath the Klyuchevskoy 
volcanic group (Kamchatka), J. Volcanol. Seismol., 2007, vol. 1, no. 2, pp. 98-118.

Koloskov, A.V., Flerov, G.B., Perepelov, A.B., Melekestsev, I.V., Puzankov, M.Yu., and Filosofova, T.M., Evolution stages and petrology of the Kekuknai volcanic massif as reflecting the magmatism in backarc zone of Kuril-Kamchatka island arc system. Part 1. Geological setting and geochemistry of volcanic rocks, J. Volcanol. Seismol., 2011, vol. 5, no. 5, pp. 312-334.

Lee Cin-Ty, A., Luffi, P., Plank, T., et al., Constraints on the depths and temperatures of basaltic magma generation on Earth and other terrestrial planets using new thermobarometers for mafic magmas, Earth and Planetary Science Letters, 2009. doi:10.1016/j. epsl.2008.12.020.

Markhinin, E.K., Stratula, D.S., and Abdurakhmanov, A.I., Undulating lava flows of Ploskii Tolbachik Volcano, Byul. Vulkanol. St., no. 49, Novosibirsk: Nauka, 1973, pp. 77-82. Mironov, N.L., The Origin and Evolution of Klyuchevskoi Magmas from the Evidence Furnished by Studies of Melt Inclusions in Olivine, Extended Abstract of Cand. Sci. (Geol.-Mineral.) Dissertation, Moscow: GEOKHI RAN, 2009.

Mironov, N.L. and Portnyagin, M.V., The concentrations of $\mathrm{H}_{2} \mathrm{O}$ and $\mathrm{CO}_{2}$ in primary magmas of Klyuchevskoi Volcano based on studies of melt and fluid inclusions in olivine, Geologiya i Geofizika, 2011, vol. 52, no. 11, pp. 1718-1735. Mysen, B. and Boettcher, A.L., Melting of hydrous mantle: II. Geochemistry of crystals and liquids formed by anatexis of mantle peridotites at high pressure and high temperatures as a function of controlled activities of water, hydrogen and carbon dioxide, J. Petrol., 1975, vol. 16, pp. 543-593.

Pearce, J.A., Stern, R.J., Bloomer, S.H., and Fryer, P., Geochemical mapping of the Mariana arc-basin system: Implication for nature and distributions of subducted components, Geochemistry, Geophysics, Geosystems (G3), 2005, vol. 6. doi:10.1029/2004GC000895.

Perepelov, A.B., The Geochemistry of Late Cenozoic High Potassium Volcanic Series in the Kamchatka Island Arc System, Extended Abstract of Cand. Sci. (Geol.-Mineral.) Dissertation, Irkutsk, 1989.

Perepelov, A.B., Neogene subalkaline magmatism of Kamchatka Sredinnyi mountain range: stages in inversion of island-arc and riftogenic geodynamic regimes (Teklektunup), in Plyumy i problema glubinnykh istochnikov shchelochnogo magmatizma (Plumes and the Problem of Deep Sources for Alkaline Magmatism), Irkutsk, 2003, pp. 242-278.

Perepelov, A.B., Neogene to Quaternary shoshonite-latite magmatism of Kamchatka's Sredinnyi mountain range: Tekletunup Volcano (geochemistry, petrology, geodynamic setting), Vulkanol. Seismol., 2005, no. 1, pp. 22-36.

Perepelov, A.B., Cenozoic Magmatism of Kamchatka during Changes of Geodynamic Settings, Extended Abstract of Dr. Sci. (Geol.-Mineral.) Dissertation, Irkutsk, 2014.

Perepelov, A.B., Puzankov, M.Yu., Ivanov, A.V., et al., Basanites of Mt. Khukhch-First mineralogic and geochemical data on Neogene $\mathrm{K}-\mathrm{Na}$ alkaline magmatism in western Kamchatka, Dokl. Akad. Nauk, 2006, vol. 408, no. 6, pp. 795-799.

Perepelov, A.B., Puzankov, M.Yu., Ivanov, A.V., et al., Neogene basanites of western Kamchatka: Mineralogical and geochemical features and the geodynamic setting, Petrologiya, 2007, vol. 15, no. 5, pp. 524-546.

Petrograficheskii kodeks Rossii. Magmaticheskie, metamorficheskie, metasomaticheskie, impaktnye obrazovaniya (Petrographic Code of Russia. Magmatic, Metamorphic, Meta- somatic, and Impact Formations), 3rd Ed., rev. and suppl., St. Petersburg: VSEGEI, 2009.

Piip, B.I., A new parasitic crater on Tolbachik Volcano, Byul. Vulkanol. St., no. 13, Moscow: AN SSSR, 1946, pp. 10-21.

Roshchina, I.A., Shevaleevskii, I.D., Korovkina, N.A., et al., X-ray fluorescence analysis of rock samples of varying composition, Sovetskaya Geologiya, 1971, no. 10, pp. 4253.

Sobolev, A.V., Sobolev, S.V., Kuz'min, D.V., et al., A mechanism for the generation of Siberian meimechites and why they are related to traps and kimberlites, Geologiya i Geofiz$i k a, 2009$, vol. 50, no. 12, pp. 1293-1334.

Sun, S. and McDonough, W.F., Chemical and isotopic systematics of oceanic basalts: Implications for mantle composition and processes, in Magmatism in the Ocean Basins, Saunders, A.D. and Norry, M.J., Eds., Geol. Soc. London Spec. Publ., 1989, vol. 42, pp. 313-345.

Tatsumi, Y., Hamilton, D.L., and Nesbitt, R.W., Chemical characteristics of fluid phase released from a subducted lithosphere and origin of arc magmas: Evidence from highpressure experiments and natural rocks, J. Volcanol. Geotherm. Res., 1994, vol. 29, pp. 293-309.

Volynets, O.N., Petrology and Geochemical Classification of Volcanic Series in a Present-Day Island Arc System, Extended Abstract of Dr. Sci. (Geol.-Mineral.) Dissertation, Moscow, 1993.

Volynets, O.N., Antipin, V.S., Perepelov, A.B., et al., The geochemistry of volcanic series of an island arc system in application to geodynamics: Kamchatka, Geologiya $i$ Geofizika, 1990, no. 5, pp. 3-13.

Volynets, O.N., Koloskov, A.V., Vinogradov, V.I., et al., Isotope composition of strontium and oxygen of the Late Cenozoic $\mathrm{K}-\mathrm{Na}$ alkaline basalts of the intraplate geochemical type, Kamchatka, Petrologiya, 1995, vol. 3, no. 2, pp. 207213.

Volynets, O.N., Karpenko, S.F., Keu, R.U., and Gorring, M., The isotope composition of Late Neogene $\mathrm{K}-\mathrm{Na}$ alkaline basaltoids in eastern Kamchatka: Signature of heterogeneity at the mantle source, Geokhimiya, 1997, no. 10, pp. 1005-1018.

Volynets, O.N., Melekestsev, I.V., Ponomareva, V.V., and Yogodzinskii, J.M., Kharchinskii and Zarechnyi Volcanoes, unique centers of Late Pleistocene magnesian basalts in Kamchatka: Composition of erupted rocks, Volcanology and Seismology, 1999, no. 1, pp. 45-66.

Volynets, A.O., Mel'nikov, D.V., and Yakushev, A.I., First data concerning the composition of ejecta discharged by the Tolbachik Fissure Eruption named after the 50-year anniversary of the Institute of Volcanology and Seismology, Kamchatka, Dokl. Akad. Nauk, 2013, vol. 452, no. 3, pp. 303-307.

Wood, D.A., A variably veined suboceanic mantle-genetic significance for mid-ocean ridge basalts from geochemical evidence, J. Geology, 1979, vol. 7, no. 3, pp. 499-503.

Wright, T.L. and Doherti, P.C., A linear programming and least squares computer method for solving petrologic mixing problem, Geol. Soc. Am. Bull., 1970, vol. 81, no. 7, pp. 95-106.

Zelenski, M., Malik, N., and Taran, Yu., Emissions of trace elements during the 2012-2013 effusive eruption of Tolbachik volcano, Kamchatka: Enrichment factors, partition coefficients and aerosol contribution, J. Volcanol. Geotherm. Res., 2014, vol. 285, pp. 136-149.

Translated by A. Petrosyan 